\title{
Sialic Acid Derivative Synthesis and Inhibitory Activities against Human Parainfluenza Virus Type 1
}

\author{
hPIV-1 シアリダーゼ阻害活性をもつシアル酸誘導体の合成
}

\author{
Ikeda, Kiyoshi \\ Department of Organic Chemistry, School of Pharmaceutical Sciences, Hiroshima International University 5-1-1, \\ Hirokoshingai, Kure, Hiroshima 737-0112, Japan \\ FAX: 81-823-73-8936,E-mail:ikeda@ps.hirokoku-u.ac.jp
}

(Received on November 19, 2010, accepted on January 25, 2011)

Key Words: sialic acid, 2-deoxy-2,3-dehydro-N-acetylneuraminic acid, sialidase inhibitors, hPIV-1 sialidase, HN glycoprotein

\begin{abstract}
Sialic acids (Neu5Ac, $\mathbf{1})$ are involved in many biological functions of glycoproteins, glycolipids, and cells. Sialidases are a family of glycosidases that catalyze the removal of $\alpha$-glycosidically linked sialic acid residues from carbohydrate groups of glycoconjugates. Among the compounds related to the sialic acid family, 2-deoxy-2,3dehydro- $N$-acetylneuraminic acids (Neu5Ac2en, 2) are known to inhibit sialidases. Human parainfluenza viruses are important respiratory tract pathogens, particularly in children. However, no vaccines or specific therapies for infections caused by these viruses are currently available. This article reviews our progress and current trends of the modification of 2-deoxy-2,3-didehydro sialic acid analogs and biological evaluations of their inhibitory activities against human parainfluenza virus type 1 (hPIV-1) sialidases.
\end{abstract}

\section{A. Introduction}

Sialic acids, such as $N$-acetylneuraminic acid (Neu5Ac), $\mathrm{N}$-glycolylneuraminic acid (Neu5Gc), and deaminoneuraminic acid (KDN), are often located at the non-reducing end of glycoconjugates on the cell surface, and play pivotal roles in many cell-surface recognition processes, cell adhesion, and viral receptor recognition (1). The most abundant sialic acid is Neu5Ac (5-acetamido-3,5-dideoxy-D-glycero-D-galactononulosonic acid, 1a) (Fig. 1). Modification of the functional groups on the sialic acid skeleton leads to changes in steric and/or electronic properties of the molecule, which can be used to probe space and charge requirements of sialic acid-
要 約

シアル酸 (Neu5Ac, 1) は糖タンパク質、糖脂質、細胞に おいて多くの生物学的機能に関わっていることが知られてい る。シアリダーゼは糖鎖から $a$-グリコシド結合したシアル 酸残基を除去するグリコシダーゼである。シアル酸関連化合 物の中で、2-デオキシ -2,3- ゙゙ヒドロ $-N$-アセチルノイラミン 酸 (Neu5Ac2en, 2) はシアリダーゼ阻害剂として知られている。 ヒューマンパラインフルエンザウイルス (human parainfluenza viruses) (hPIVs) は特に、子供に重篤な呼吸器疾患を引き起こ す。しかし、現在、これらのウイルスによる感染症に対して ワクチンや有効な治療法はない。この総説では Neu5Ac2en 誘 導体合成に関する我々の研究と最近の動向、さらにヒューマ ンパラインフルエンザウイルス タイプ1型 (hPIV-1) シアリ ダーゼに対する阻害活性について紹介する。

A. はじめに

シアル酸は、たとえば Neu5Ac、Neu5Gc、KDN として、 細胞表面上の糖鎖の非還元末端にあり、多くの細胞表面の認 識、細胞接着抢よびウイルスのレセプター認識 (1) で重要な役 割を担っている。もっとも多く存在するシアル酸は $N$ - アセチ ルノイラミン酸 (Neu5Ac, 1a) である (図 1)。シアル酸骨格上 の官能基の化学修飾により、分子の立体的、電子的な特性に 変化を与え、それによりシアル酸を認識するタンパク質のリ ガンド認識部位の空間の広がりや、必要とされる電荷を調べ ることができる $(2) 。$

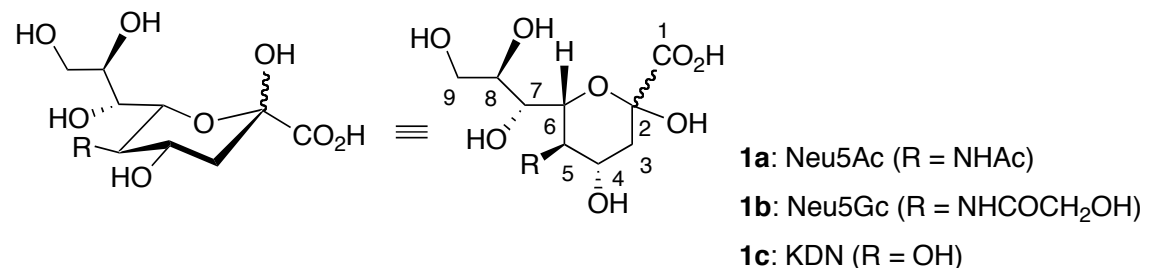

Fig. 1. Structures of sialic acids. 
recognizing proteins (2).

Human parainfluenza viruses (hPIVs), members of the Paramyxoviridae family, are important respiratory tract pathogens in infants and children. Four different types of hPIVs have been identified, all of which cause a spectrum of illnesses of the upper and lower respiratory tracts of children (3). There are currently no effective vaccines or specific therapies available for controlling parainfluenza virus infections. Parainfluenza virus contains 2 spike glycoproteins, hemagglutinin-neuraminidase (HN) glycoproteins, and fusion (F) glycoprotein, embedded in the envelope. HN proteins recognize sialic acid-containing glycolipids and glycoproteins of target cells; this recognition allows the virus to bind to target cells. Furthermore, HN proteins act as a sialidase, removing sialic acid from virus particles, and thus preventing self-aggregation and promoting efficient spread of the virus. The multifunctional role of HN in the viral life cycle makes it an attractive target for the development of chemotherapeutics to treat hPIV infection. In this minireview, we outline recent studies involving sialic acid modifications, including our work and current trends in the design, synthesis, and biological evaluation of Neu5Ac2en analogs against hPIV sialidase.

\section{B. Analogs of 2-Deoxy-2,3-Didehydro Sialic Acids}

Neu5Ac2en 2 (4) may be a transition state analog that binds to the active site of sialidase. It has been identified as an inhibitor of sialidase using both bacterial and viral sources, occupying an important position in modern medicinal chemistry (5). Synthesis of sialic acid derivatives may be applicable in the development of pharmaceutical agents.

Using molecular modeling techniques, von Itzstein et al. reported the design and biological evaluation of 4-amino4-deoxy- (3) and 4-deoxy-4-guanidino-Neu5Ac2en analogs (4) (zanamivir) (6). These compounds significantly increase inhibition of influenza A and B virus sialidases compared with Neu5Ac2en alone. In particular, compound 4 exhibited selective inhibition of the virus over mammalian sialidase and was approved for human use. Further, potent and selective inhibition of influenza virus sialidase by $\mathbf{4}$ has prompted the synthesis of a range of structural variants of these compounds. For example, the non-carbohydrate derivatives such as a heterocyclic compound (5) (7) and a carbocyclic compound (6) (8) were developed.

Recently, Honda et al. reported that 7-O-methyl-
hPIVs は、Paramyxoviridae family に属し、小児や子供 にとって重大な呼吸器の病原ウイルスである。hPIVs には4 つの異なる夕イプが同定されており、これらのすべてが子供 の上気道、下気道の呼吸器における病原性スペクトルをもっ ている (3)。現在、パラインフルエンザウイルス（hPIV）感 染を制御する有効なワクチンや治療法は皆無である。hPIVs には、細胞表面上に二つのスパイク状の糖タンパク質、 hemagglutinin-neuraminidase (HN) および fusion $(\mathrm{F})$ 糖タンパ ク質が埋め込まれている。この HN 糖タンパク質は標的細胞 のシアル酸を含んだ糖脂質や糖タンパク質を認識し、これに よりウイルスが標的細胞に結合することができる。さらに HN タンパク質はシアリダーゼとしても働き、ウイルス粒子から シアル酸を除去し、それによってウイルスの自己縮合を抑え、 ウイルスの効率的な拡散を促進している。hPIV の生活環の中 で果たす HN 糖タンパク質の多機能な性質は、hPIV 感染を 治療する化学療法剤開発のための魅力的なターゲットである。 このミニレビューでは、シアル酸の修飾に関する我々の研究 や最近のデザインと合成の動向、そして hPIV シアリダーゼ に対する活性評価について紹介する。

\section{B. 2- デオキシ -2,3- デヒドロ - シアル酸誘導体}

Neu5Ac2en 2 (4) は、シアル酸残基が加水分解される際の 遷移状態アナログであり、バクテリアやウイルスを根源とし たシアリダーゼの阻害剤として認められており、医薬品化学 では重要な立場にある (5) ( 図 2)。シアル酸誘導体の合成は創 薬研究の観点から大変興味がもたれている。

von Itzstein らは分子モデリング技術により、4-アミノ-4デオキシ - (3) や 4- デオキシ -4-グアニジノ -Neu5Ac2en アナ ログ (4) (zanamivir) を考案し、インフルエンザウイルスに対 する阻害活性を報告した (6)。これらの化合物はインフルエン ザ $\mathrm{A}$ および $\mathrm{B}$ シアリダーゼに対して 2 よりも強力な阻害作用 を示した。特に、4 は哺乳動物シアリダーゼよりも選択的にウ イルスシアリダーゼに阻害作用を示し臨床応用された。さら に、4は強力で選択的なウイルス阻害剤であることから、種々 の誘導体の合成が行われてきた。たとえば 4 に関連した阻害 剂として、ヘテロ環化合物 (5) (7) や 2 のジヒドロピラン環を 非糖化合物で置き換えたカルボサイクル化合物 (6) (8) が合成さ れた（図 3)。

最近、本田らは 4-グアジニノ-Neu5Ac2en 骨格をもつ

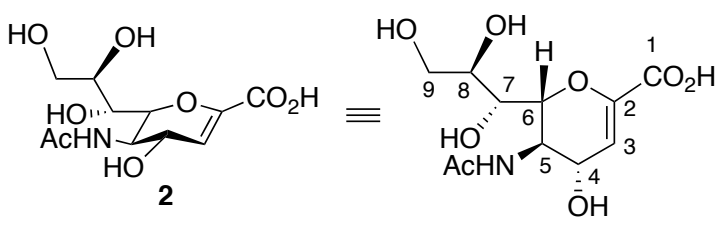

Fig. 2. Structure of Neu5Ac2en. 


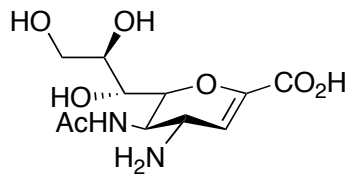

3: 4-amino-Neu5Ac2en

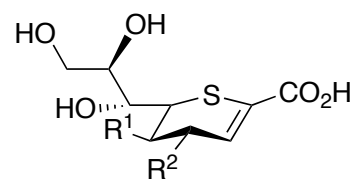

5: $\mathrm{R}^{1}=\mathrm{NHAc}, \mathrm{R}^{2}=\mathrm{NH}_{2}, \mathrm{NHC}(\mathrm{NH}) \mathrm{NH}_{2}$

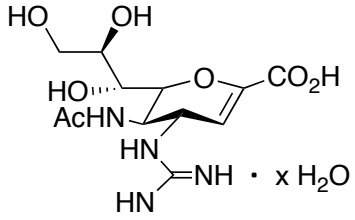

4: 4-guanidino-Neu5Ac2en (Zanamivir hydrate, Rilenza ${ }^{\circledR}$ )

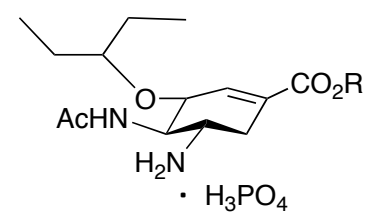

6: $\mathrm{R}=\mathrm{Et}\left(\right.$ Oseltamivir phosphate, Tamiflu ${ }^{\circledR}$ )

Fig. 3. Sialidase inhibitors.

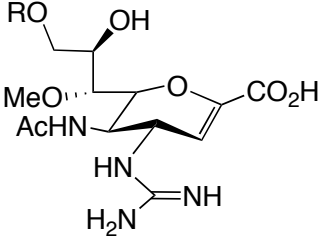

7a: $\mathrm{R}=-\mathrm{H}$

7b: $\mathrm{R}=-\mathrm{C}(\mathrm{O})\left(\mathrm{CH}_{2}\right)_{6} \mathrm{CH}_{3}$

Fig. 4. Zanamivir derivatives.
Neu5Ac2en derivative (7a) and 7-O-methyl-9-O-octanoylNeu5Ac2en sialidase inhibitor (7b), carrying a 4-guanidinoNeu5Ac2en framework, inhibited influenza virus replication much more effectively than zanamivir did (9) (Fig. 4). Compound $\mathbf{7 b}$, an octanoyl ester prodrug of the C-9 alcohol of 7a, was found to be much longer acting than zanamivir, and was recently approved for human use.

\section{4,9-O-Disubstituted 2-Deoxy-2,3-Didehydro Neu5Ac2en Analogs}

Crystallographic information regarding Newcastle disease virus (NDV) HN glycoprotein with Neu5Ac2en 2 showed that interactions near the carboxy group of 2 were very similar to those seen in other sialidase-Neu5Ac2en complexes. Furthermore, the amino acid residues interacting with C-7, C-8, and C-9 glycerol side chains and the C-5 acetamido group were largely conserved across 7 paramyxoviruses, including hPIV-1, although the catalytic pocket possessed a large cavity in the direction of the 4-hydroxy group of $\mathbf{2}$ as compared with those of influenza virus and bacterial sialidases (10). These structural findings indicated that suitable modification at the C-4 position of $\mathbf{2}$ for the large cavity of the $\mathrm{HN}$ glycoprotein has important effects in the design of potent inhibitors against sialidase from hPIV. Portner et al. reported that compounds BCX 2798 (8a) and BCX 2855 (8b) with modifications at C-4 and $\mathrm{C}-5$ positions of $\mathbf{2}$ of which designs were based on the crystal structure of the HN of NDV were specific and potent inhibitors of hPIVs (11). (Fig. 5) A reported X-ray structure
7-O-メチル -Neu5Ac2en 誘導体 (7a) や 7-O-メチル -9-O-オク タノイル -Neu5Ac2en シアリダーゼ 阻害剂 (7b) が、4 に比較 してインフルエンザウイルスの複製をより有効に阻害するこ とを報告した (9)（図 4)。化合物 7b は、9 位水酸基にオク夕 ノイル基を持つ $\mathbf{7 a}$ のプロドラッグであり、長時間持続型であ ることから最近臨床応用された。

C. 4,9-O-二置換 -2- デオキシ -2,3- デヒドロ - シアル酸誘導体 Newcastle disease virus (NDV)の HN 糖タンパク質と 2 との複合体の結晶構造解析から、NDV はその触媒部位にイン フルエンザやバクテリアのシアリダーゼと比較して 2 の 4 位 水酸基の方向に大きな空洞をもっているが、2 のカルボキシ ル基の周りの相互作用は、他のシアリダーゼと非常に類似し て扔り、グリセロール鎖の C-7、C-8、C-9 の水酸基と C-5 位 アセトアミド基に相互作用するアミノ酸残基は hPIV-1 を含め て7つの paramyxoviruses でよく保存されていることが明ら かにされている (10)。これら構造上の知見から、HN 糖タンパ ク質の空洞に適合するように 2 の C-4 位を修飾することは、 hPIV シアリダーゼに対する強力な阻害剂を考案するために重 要である。Portner らは、NDV の HN の X 線結晶構造解析か ら hPIV 阻害剤のデザインによる新規な BCX 2798 (8a) およ び BCX 2855 (8b) を合成し、それらが hPIV-1 および hPIV-3 シアリダーゼに対して特異的で有効な阻害物質であることを 報告した (11) (図 5)。この研究の後、hPIV-3 HN 糖タンパク質 の X 線結晶構造が報告 (12) されたことから、今後、その構造

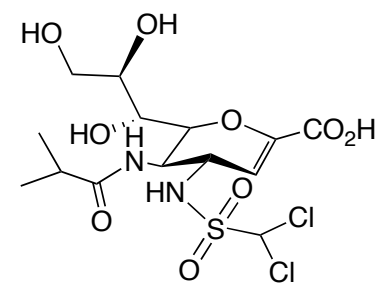

8b: BCX-2855

Fig. 5. Structures of BCX-2798 and BCX-2855. 


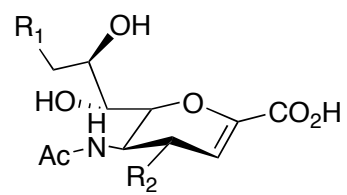

$$
\begin{aligned}
& \text { 9a: } R_{1}=O H, R_{2}=O^{O C H} C_{2} C N \\
& \text { 9b: } R_{1}=O H, R_{2}=O C H_{2} C(=O) N_{2} \\
& \text { 9c: } R_{1}=O H, R_{2}=O C H_{2} C(=N H) N_{2} \\
& \text { 9d: } R_{1}=O H, R_{2}=O C H_{2} C(=S) N_{2} \\
& \text { 11a: } R_{1}=N H A c, R_{2}=O C H_{2} C(=S) N_{2} \\
& \text { 11b: } R_{1}=N H A c, R_{2}=O C H_{2} C N \\
& \text { 11c: } R_{1}=N H A c, R_{2}=O C H_{2} C(=O) N_{2} \\
& \text { 11d: } R_{1}=N H A c, R_{2}=O C H_{2} C(=N H) N_{2}
\end{aligned}
$$$$
\text { 10a: } R_{1}=N_{3}, R_{2}=O_{2} C N
$$$$
\text { 10b: } R_{1}=N_{3}, R_{2}=O_{2} H_{2} \mathrm{C}(=O) \mathrm{NH}_{2}
$$$$
\text { 10c: } R_{1}=N_{3}, R_{2}=O C H_{2} C(=N H) N_{2}
$$$$
\text { 10d: } \mathrm{R}_{1}=\mathrm{N}_{3}, \mathrm{R}_{2}=\mathrm{OCH}_{2} \mathrm{C}(=\mathrm{NH}) \mathrm{OMe}
$$

\section{Fig. 6. 4,9-O-Disubstituted Neu5Ac2en derivatives.}

model of hPIV-3 HN (12) will allow for further directed, structure-based design of potential hPIV-3 inhibitors. Although the amino acid sequences of hPIV-1 surface glycoproteins have been described $(10,13)$, the crystal structure model of a complex of hPIV-1 HN glycoprotein and $\mathbf{2}$ is undetermined.

To ascertain the influence of the 4-hydroxyl group in $\mathbf{2}$ on the inhibitory activities towards sialidase, Neu5Ac analog hydroxyl groups at C-4 were replaced with cyanomethyl, carbamoylmethyl, amidinomethyl, methoxyiminomethyl, and thiocarbamoylmethyl groups. Furthermore, the hydroxyl group at C-9 was modified using azide or $\mathrm{N}$-acetyl groups to determine whether the 9-hydroxyl group in $\mathbf{2}$ is important for inhibiting sialidases from various sources. We present the synthesis of Neu5Ac2en derivatives $(\mathbf{9}, \mathbf{1 0}$, and 11) modified at the C-4 and C-9 positions of $\mathbf{2}$ and evaluations of their inhibitory activities against sialidases from both viral and mammalian sources (14) (Fig. 6).

Compounds 12, 13, and 14, bearing a cyanomethyl group (15) at the C-4 position, were selected as key intermediates for the preparation of 9a-d, 10a-d, and 11a-d in our synthesis. Cyanomethyl is a versatile functional group used for preparing sugar amides and amidine salts, which may induce new electrostatic and/or hydrogen-bonding interactions. C-4 modified Neu5Ac2en derivative 9a-d was synthesized as shown in Scheme 1. After a cyanomethyl group was selectively introduced at the C-4 alcohol of $\mathbf{1 6}$ and after the isopropylidene group was successively removed followed by acetylation, compound $\mathbf{1 8}$ was transformed by treatment with dimethyl(methylthio)sulfonium triflate (DMTST and DBU) (16) to develop compound 12. Intermediate $\mathbf{1 2}$ in turn was transformed into 9a-c. Thus, deacetylation of $\mathbf{1 2}$ followed by hydrolysis yielded the cyanomethyl compound 9a. Next, for synthesizing the carbamoylmethyl compound $\mathbf{9 b}, \mathbf{1 2}$ was treated with $\mathrm{NaOMe}$ followed by aqueous $\mathrm{NaHCO}_{3}$ to yield $\mathbf{9 b}$. For the synthesis of the amidinomethyl compound $\mathbf{9 c ,}, \mathbf{1 2}$ was successively treated with $\mathrm{NaOMe}$, anhydrous $\mathrm{NH}_{4} \mathrm{Cl}$, and then $\mathrm{KOH}$ to generate $9 \mathrm{c}$. After thioamidomethylation by
情報に基づき hPIV-3 の強力な阻害剤のデザインが可能になる であろう。hPIV-1の表面糖タンパク質のアミノ酸配列はすで に明らかにされているが $(10,13) 、 h P I V-1 ~ H N$ 糖タンパク質と 2 との複合体の結晶構造はまだ解明されていない。

図 5 シアル酸の 4 位の置換基のシアリダーゼ阻害活性に 及ぼす影響を確かめるために、シアル酸の C-4 位水酸基をシ アノメチル、カルバモイルメチル、アミジノメチル、メトキ シイミノメチル拉よびチオカルバモイルメチル基に変換した。 さらに、C-9 位の水酸基が様々な起源のシアリダーゼの阻害に 重要かどうか検討するために、9 位水酸基をアジド基や $N$ - ア セチル基で修飾した。この項では、2 の C-4，9位を修飾した シアル酸誘導体 $(9,10,11)$ の合成と、ウイルスや哺乳動物を起 源とするシアリダーゼに対する阻害活性について述べる (14) (図 6)。

C-4 位にシアノメチル基を持つ化合物 12、13、14 の合成 には、9a-d、10a-d、11a-d を鍵化合物として選んだ。シアノ メチル基 (15) は糖アミドやアミジノ体合成のための多目的な 官能基であり、新たな静電気力や水素結合による相互作用を 強力に誘起することができる。C-4 位を修飾した Neu5Ac2en 誘導体 9a-d の合成はスキーム 1 に示した。16の C-4 位の水 酸基に選択的にシアノメチル基を導入し、次にイソプロピリ デン基を除去し、アセチル化後、18 は dimethyl(methylthio)s ulfonium triflate (DMTST) と DBU (16) により鍵化合物 $\mathbf{1 2}$ へ 誘導した。さらに、鍵化合物 12 は 9a-c へと導いた。まず、 12 の脱アセチル化、加水分解によりシアノメチル体 9a とし た。次に、カルバモイルメチル体 9b の合成は、12 をナトリ ウムメトキシド、そして 炭酸水素ナトリウムで処理すること により 9b とした。アミジノメチル体 9c の合成は、12 をナト リウムメトキシド、塩化アンモニウムそして水酸化カリウム で連続的に処理して 9c とした。9d はチ才酢酸によるチオア 
Scheme 1. Reagents and conditions. (a) (i) $0.1 \mathrm{M}$ $\mathrm{NaOMe}-\mathrm{CH}_{2} \mathrm{Cl}_{2}-\mathrm{MeOH}$, (ii) IR120 $\left(\mathrm{H}^{+}\right.$), acetone, $81 \%$ (two steps); (b) (i) $\mathrm{BrCH}_{2} \mathrm{CN}, \mathrm{Ag}_{2} \mathrm{O}$, TBAI, DMF, (ii) $80 \% \mathrm{AcOH}$, $47 \%$ (two steps); (c) $\mathrm{Ac}_{2} \mathrm{O}$, pyridine, 98\%; (d) (i) DMTST, $\mathrm{CH}_{2} \mathrm{Cl}_{2}$, (ii) DBU, 97\%; (e) 0.1 $\mathrm{M} \mathrm{KOH}-\mathrm{MeOH}, 49 \%$; (f) (i) $0.1 \mathrm{M} \mathrm{NaOMe}-\mathrm{MeOH}$, (ii) aq. $\mathrm{NaHCO}_{3}, 55 \%$ (two steps); (g) (i) $0.1 \mathrm{M} \mathrm{NaOMe}-\mathrm{MeOH}$, (ii) anhydr. $\mathrm{NH}_{4} \mathrm{Cl}$, (iii) $0.1 \mathrm{M} \mathrm{KOH}-$ $\mathrm{MeOH}, 57 \%$ (three steps); (h) AcSH, pyridine, $94 \%$; i) $0.1 \mathrm{M}$ $\mathrm{KOH}-\mathrm{MeOH}, 52 \%$.

AcSH-pyridine followed by hydrolysis, $9 \mathbf{d}$ was produced.

For the synthesis of $\mathbf{1 0 a}-\mathbf{d}$, bearing an azido group at C-9, $\mathbf{1 7}$ was converted to the common intermediate $\mathbf{1 3}$ (Scheme 2). Selective tosylation at the C-9 alcohol of $\mathbf{1 7}$, subsequent treatment with $\mathrm{NaN}_{3}$, and acetylation generated 22. Compound 22 was similarly treated with DMTST and then DBU to yield 13. Similar to the preparation of $\mathbf{9 a - c , ~} \mathbf{1 3}$ was converted into the corresponding cyanomethyl compound 10a, carbamoylmethyl compound 10b, and amidinomethyl compound 10c. Furthermore, 13 was treated with $\mathrm{NaOMe}$, and then hydrolyzed to yield $\mathbf{1 0 d}$.
Scheme 2. Reagents and conditions. (a) $\mathrm{TsCl}$, pryridine, 64\%; (b) $\mathrm{NaN}_{3}, 18$-crown-6, 74\%; (c) $\mathrm{Ac}_{2} \mathrm{O}$, pyridine, $95 \%$; (d) (i) DMTST, (ii) DBU, 99\%; (e) $0.1 \mathrm{M}$ $\mathrm{KOH}-\mathrm{MeOH}, 80 \%$; (f) (i) $0.1 \mathrm{M}$ $\mathrm{NaOMe}-\mathrm{MeOH}$, (ii) aq. $\mathrm{NaHCO}_{3}$, 67\% (two steps); (g) (i) $0.1 \mathrm{M}$ $\mathrm{NaOMe}-\mathrm{MeOH}$, (ii) anhydr. $\mathrm{NH}_{4} \mathrm{Cl}$, (iii) $0.1 \mathrm{M} \mathrm{KOH}-\mathrm{MeOH}, 60 \%$ (three steps); (h) (i) $0.1 \mathrm{M} \mathrm{NaOMe}-\mathrm{MeOH}$, (ii) $0.1 \mathrm{M} \mathrm{KOH}-\mathrm{MeOH}, 76 \%$ (two steps).

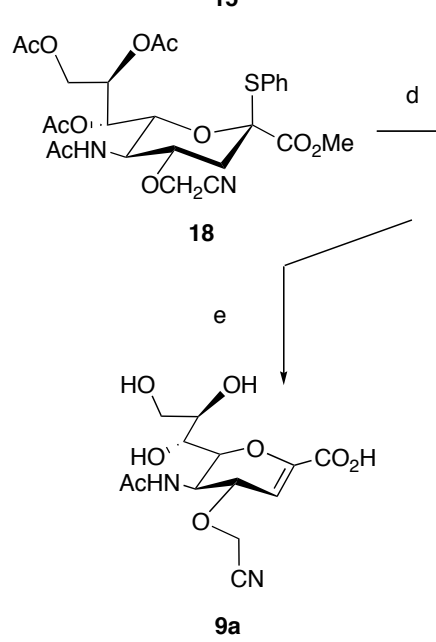

ミドメチル化、加水分解により得た。

C-9 位にアジド基を持つ 10a-d の合成には、17 を共通中 間体 13 へと誘導した (スキーム 2)。17 の C-9 位水酸基の選 択的トシル化、続くアジド化、アセチル化により 22 が得られ た。化合物 22 は同様に DMTST と DBU により 13 とした。 9a-c の合成と同様に、13 は対応するシアノメチル体 10a、カ ルバモイルメチル体 10b、アミジノメチル体 10c へと変換した。 さらに、13 はナトリウムメトキシド、そして加水分解により 10dが得られた。

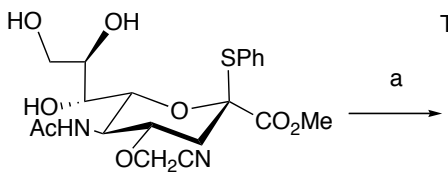

17

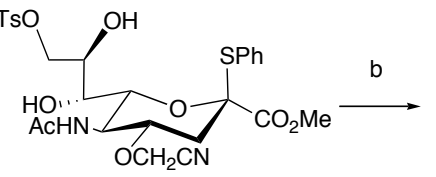

20

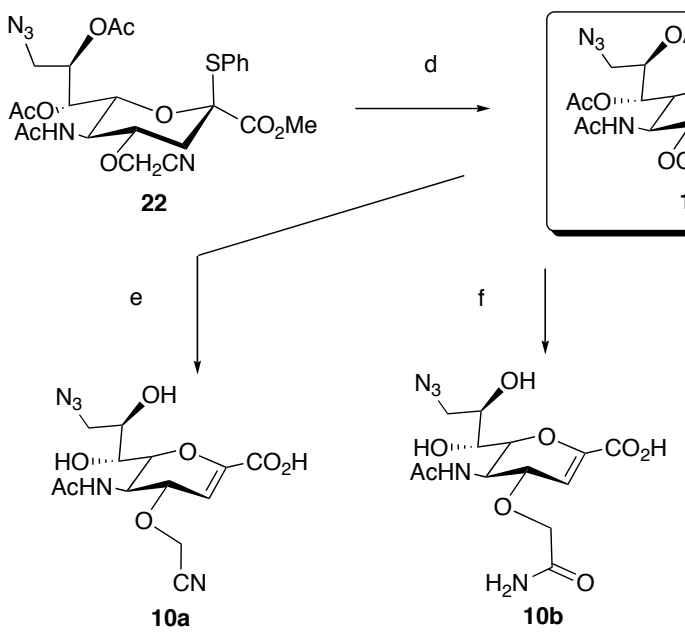

18

C2011 FCCA (Forum: Carbohydrates Coming of Age) 

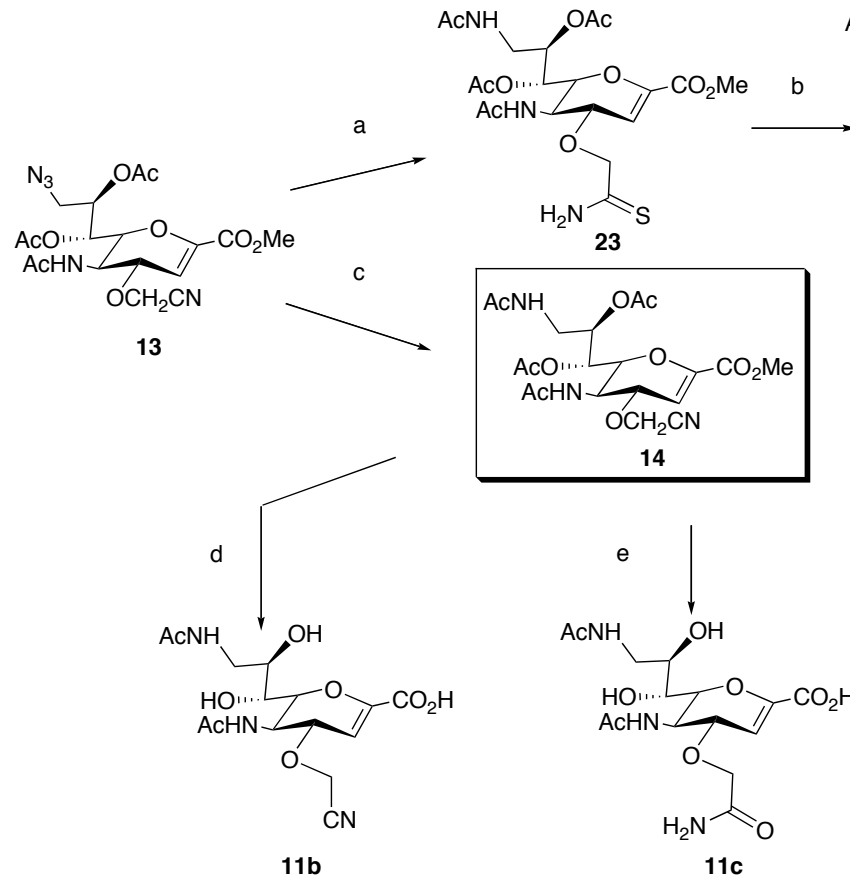

For the synthesis of 11a-d with an $N$-Ac group at $\mathrm{C}-9$, transformation to the common intermediate $\mathbf{1 4}$ from $\mathbf{1 3}$ was examined (Scheme 3). After reduction of the azido group of $\mathbf{1 3}$, simultaneous acetylation generated $\mathbf{2 3}$, which was hydrolyzed to give thiocarbamoylmethyl compound 11a. The azido group of $\mathbf{1 3}$ was reduced using $\mathrm{PPh} 3$, and following acetylation, compound $\mathbf{1 4}$ was produced. Similarly to the method described above, $\mathbf{1 4}$ was transformed to the corresponding cyanomethyl compound $\mathbf{1 1} \mathbf{b}$, carbamoylmethyl compound 11c, and amidinomethyl compound 11d.

The behavior of these newly synthesized compounds toward sialidase from influenza virus A/Memphis/1/71 $\left(\mathrm{H}_{3} \mathrm{~N}_{2}\right)$ and pig liver membrane was examined by comparing inhibition activity to that of $\mathbf{2}$ (Table I). Additionally, we examined the inhibitory activities of synthesized compounds toward hPIV-1 sialidase (Table II). As can be seen from Table I, compounds 10d and 11c,d showed inhibitory activities against both sialidases. However, the inhibition degree of $\mathbf{1 1 c , d}$ was less than that of $\mathbf{2}$. Additionally, compound 10d was essentially inactive against hPIV-1 sialidase. Interestingly, compound 11a exhibited selective inhibition against the virus over mammalian sialidase, while the inhibitory effects of $\mathbf{1 0 b}, \mathbf{c}$ were only on mammalian sialidase. The most effective compound in this study was thiocarbamoylmethyl analog $9 \mathrm{~d}$, whose $\mathrm{IC}_{50}$ of approximately $10 \mu \mathrm{M}$ toward hPIV-1 sialidase was 30 -fold smaller than that of $\mathbf{2}$. Analogs of $\mathbf{2}$ modified at the $\mathrm{N}$-acetyl group on C-9 showed decreased inhibition of hPIV-1 sialidase compared with 9-hydroxy analogs. Modification at the C-9 hydroxyl group of 2 with nitrogen substituents did not significantly enhance biological activity.

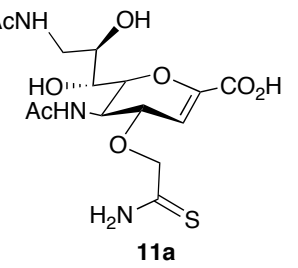

Scheme 3. Reagents and conditions. (a) $\mathrm{AcSH}$, pyridine, 79\%; (b) $0.1 \mathrm{M} \mathrm{KOH}-\mathrm{MeOH}, 67 \%$; (c) (i) $\mathrm{PPh}_{3}$-dioxane- $\mathrm{MeOH}-\mathrm{H}_{2} \mathrm{O}$, (ii) $\mathrm{Ac}_{2} \mathrm{O}$, pyridine, $85 \%$ (two steps); (d) $0.1 \mathrm{M} \mathrm{KOH}-\mathrm{MeOH}, 41 \%$; (e) (i) 0.1 $\mathrm{M} \mathrm{NaOMe}-\mathrm{MeOH}$, (ii) aq. $\mathrm{NaHCO}_{3}$, $60 \%$ (two steps); (f) (i) $0.1 \mathrm{M} \mathrm{NaOMe-}$ $\mathrm{MeOH}$, (ii) anhydr. $\mathrm{NH}_{4} \mathrm{Cl}$, (iii) $0.1 \mathrm{M}$ $\mathrm{KOH}-\mathrm{MeOH}$ 52\% (three steps).

C-9 位に $N$-アセチル基を持つ 11a-d を合成するために、 13 から共通中間体 14 への誘導を検討した（スキーム 3 ）。13 のアジド基の還元、同時にアセチル化により 23 とし、加水分 解によりチオカルバモイルメチル体 11a が得られた。13 のア ジド基はトリフェニルホスフィンによる還元、アセチル化に より 14 とした。同様に、14 は対応するシアノメチル体 11b、 カルバモイルメチル体 11c、アミジノメチル体 11d に変換した。

今回合成した新規化合物のインフルエンザ A およびブタ 肝膜シアリダーゼに対する影響を 2 と比較検討した（表 I）。 さらに、hPIV-1 シアリダーゼに対する合成化合物と 2 との 阻害活性の比較も行った (表 II)。表 I から、化合物 $\operatorname{10d}$ と 11c,d はいずれのシアリダーゼにも阻害活性を示した。しか し、11c,d の活性の度合いは 2 と比較して弱かった。また 10d は hPIV-1 シアリダーゼには有効ではなかった。興味あること に、11aは哺乳動物のシアリダーゼよりもウイルスシアリダー ゼに選択的な阻害作用を示した。今回、チオカルバモイルメ チル誘導体 9d が最も有効であり、その hPIV-1 シアリダーゼ に対する阻害活性 $\left(\mathrm{IC}_{50}\right)$ は $10 \mu \mathrm{M}$ で 2 の 30 倍であった。一 方、 $N$ - アセチル基で修飾した 2 の誘導体 (11a-d) は 9 位水酸 基体と比較して hPIV-1 シアリダーゼに対して阻害活性は減少 した。9 位水酸基を窒素置換基で修飾しても生物活性の向上に は有効な影響はなかった。これらの結果は、C-7、C-8 および C-9 のグリセロール側鎖は paramyxovirus HN 糖タンパク質 
Table I. Inhibitory activities against virus and mammalian sialidases.

Table II. Inhibitory activities against hPIV-1.

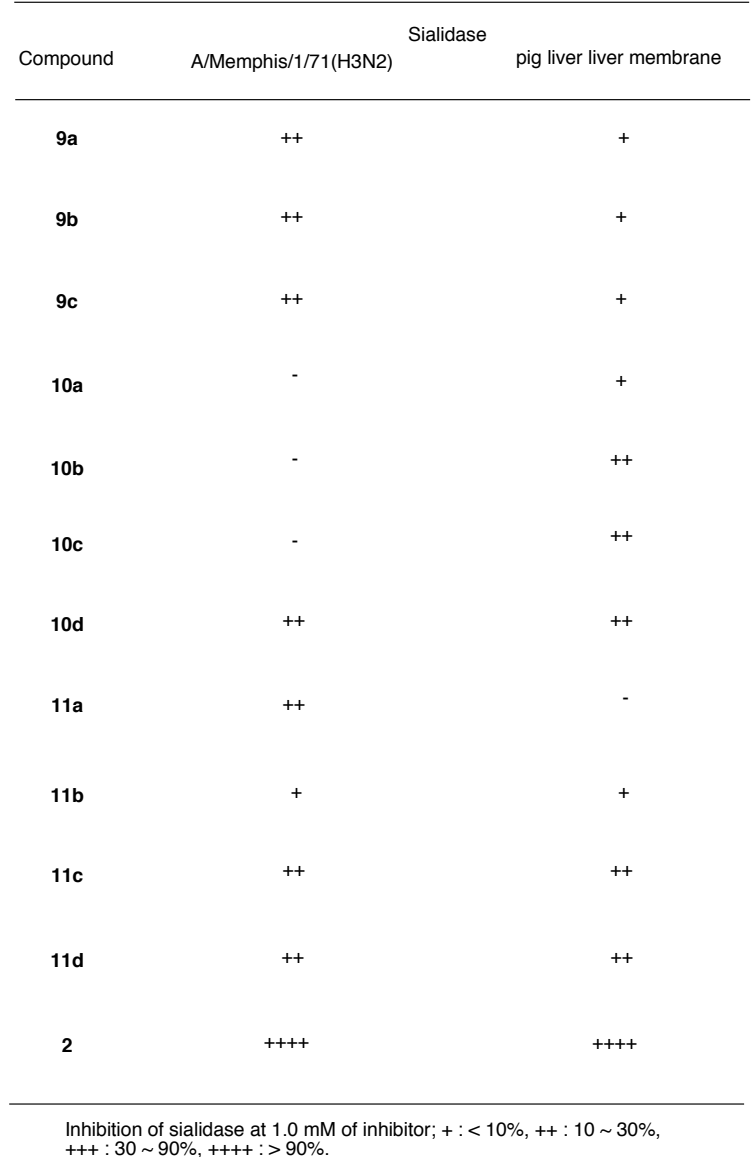

\begin{tabular}{cc}
\hline Compound & $\mathrm{IC}_{50}(\mu \mathrm{M})$ \\
\hline $\mathbf{1 1 a}$ & 42 \\
$\mathbf{9 a}$ & 60 \\
$\mathbf{9 c}$ & 100 \\
$\mathbf{9 d}$ & 10 \\
$\mathbf{2}$ & 300
\end{tabular}

+++ : $30 \sim 90 \%,++++$ : $>90 \%$.

These results support structural findings regarding the NDV HN glycoprotein. The C-7, C-8, and C-9 glycerol side chains are distinctive features of paramyxovirus $\mathrm{HN}$ glycoproteins and important determinants of sialic acid recognition. Compound 9d may fit in the cavity of the hPIV-1 HN glycoprotein better than other analogs tested. Furthermore, the inhibitory activity of 9d towards hPIV-3 sialidase was not significantly affected in comparison with the activity of $\mathbf{2}$ and 4-guanigino-Neu5Ac2en 4.

\section{4-O-Thiocarbamoylalkyl-2-Deoxy-2,3-Didehydro- Neu5Ac2en Analogs}

We found that 4-O-thiocarbamoylmethyl-Neu5Ac2en (9d) has strong inhibitory activity toward hPIV-1 sialidase compared with that of 2 . Therefore, we compared the inhibitory activity against hPIV-1 sialidase of a few thiocarbamoylalkyl groups on the hydroxyl group at the C-4 position. In this section, we present the synthesis of analogs possessing thiocarbamoylethyl $\mathbf{2 7}$ and thiocarbamoylpropyl $\mathbf{2 8}$ groups at the C-4 position of $\mathbf{2}$ and their inhibitory activities against hPIV-1 sialidase (17). As outlined in Scheme 4, the synthesis of compounds 27 and 28 began with intermediate compounds $\mathbf{2 5}$ and $\mathbf{2 6}$, respectively.

First, for synthesis of $\mathbf{2 7}$, a reaction of $\mathbf{2 4}$ with
の認識に必要であり、シアル酸を認識するための重要な決定 要素であるという NDV HN 糖タンパク質の構造的な知見を支 持している。化合物 9d は他の誘導体に比較して hPIV-1 HN 糖タンパク質の空洞に適合していたと考えられる。さらに $9 \mathrm{~d}$ の hPIV-3 に対する阻害活性には 2 や 4 に比較して顕著な差 は見られなかった。

D. 4-O- チオカルバモイルアルキル -2- デオキシ -2,3- デヒド ロ - シアル酸誘導体

4-O-チオカルバモイルメチル -Neu5Ac2en 9d が hPIV-1 シアリダーゼに対して強い阻害活性をもつことを見出した。 次に、C-4 位の水酸基に置換したチオカルバモイルアルキル基 の hPIV-1 シアリダーゼに対する阻害活性を比較した。この項 では、2 の C-4 位にチオカルバモイルエチル基 27 およびチオ カルバモイルプロピル基 28 をもつ誘導体の合成と、生物活性 の検討について述べる (17)。スキーム4 に示したように、27 と 28 の合成は鍵化合物 25 と 26 からそれぞれ行った。

まず、27 の合成は、水素化ナトリウム存在下、24 と 3-ブ 


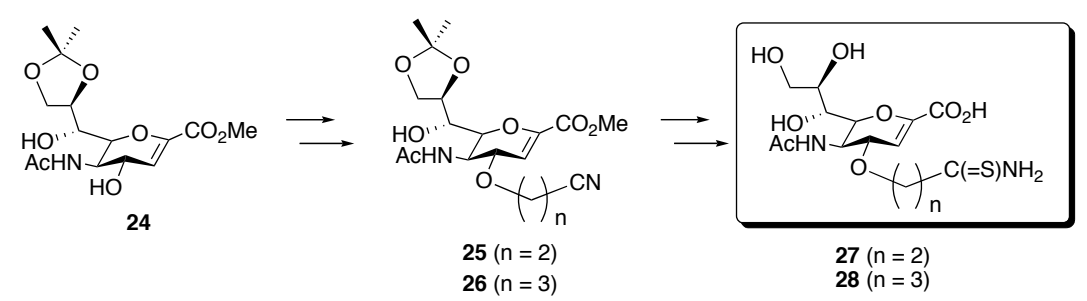

Scheme 4. Synthesis of 27 and 28.

Table III. Synthesis of 25 and 26.

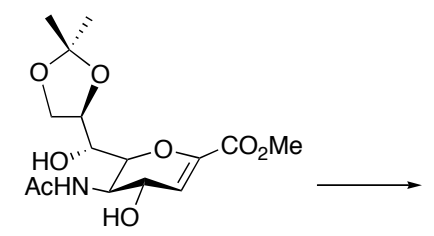

24

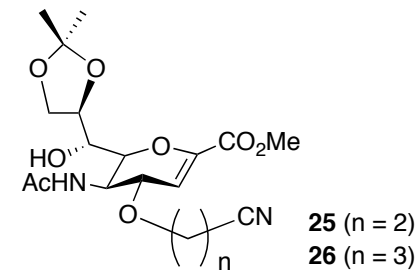

\begin{tabular}{|c|c|c|c|c|}
\hline Entry & Conditions & Time (h) & Products & Yields (\%) \\
\hline 1 & $\mathrm{BrCH}_{2} \mathrm{CH}_{2} \mathrm{CN}, \mathrm{NaH}$, DMF, r.t. & 1 & 25 & N.R. ${ }^{a}$ \\
\hline 2 & $\mathrm{BrCH}_{2} \mathrm{CH}_{2} \mathrm{CN}, \mathrm{Ag}_{2} \mathrm{O}$, TBAI, DMF, $50^{\circ} \mathrm{C}$ & 12 & 25 & 58 \\
\hline 3 & $\mathrm{CH}_{2}=\mathrm{CHCN}, \mathrm{DBU}, \mathrm{CH}_{3} \mathrm{CN}, 0^{\circ} \mathrm{C}$ & 12 & 25 & 70 \\
\hline 4 & $\mathrm{BrCH}_{2} \mathrm{CH}_{2} \mathrm{CH}_{2} \mathrm{CN}, \mathrm{NaH}$, DMF, r.t. & 1 & 26 & 50 \\
\hline 5 & $\mathrm{BrCH}_{2} \mathrm{CH}_{2} \mathrm{CH}_{2} \mathrm{CN}, \mathrm{Ag}_{2} \mathrm{O}$, TBAI, DMF, r.t. & 12 & 26 & 70 \\
\hline
\end{tabular}

a No reaction.

3-bromopropionitrile in the presence of sodium hydride resulted in the recovery of $\mathbf{2 4}$ by $\beta$-elimination of the 4- $O$-thiocarbamoylethyl moiety of $\mathbf{2 5}$ due to a retro-Michael reaction which occurred under strongly basic conditions (Table III, entry 1). Selective 4-O-cyanoethylation of $\mathbf{2 4}$ with 3 -bromopropionitrile using silver oxide gave 4-O-cyanoethyl derivative 25 (entry 2). Interestingly, Michael addition reaction of $\mathbf{2 4}$ with acrylonitrile in the presence of DBU proceeded to give 25 (entry 3). For preparation of 28, 4-O-cyanopropylation of $\mathbf{2 4}$ with 4-bromobutyronitrile in the presence of sodium hydride successfully generated 4- $O$-cyanopropyl derivative 26 (entry 4). The reaction of 4-bromobutyronitrile and silver oxide gave compound $\mathbf{2 6}$ (entry 5).

Thiocarbamoylalkylation of the C-4 position on $\mathbf{2 5}$ and 26 using a previously reported method (18) with AcSHpyridine did not proceed. Therefore, deprotection of $\mathbf{2 5}$ and $\mathbf{2 6}$ generated alcohols were acetylated to give cyanoalkyl compounds $\mathbf{2 9}$ and $\mathbf{3 0}$, respectively (Scheme 5).

For conversion of cyanoalkyl groups of $\mathbf{2 9}$ and $\mathbf{3 0}$ to a thiocarbamoyl group, we examined thiocarbamoylation of 29 and $\mathbf{3 0}$ using $\mathrm{AcSH}$-pyridine in $\mathrm{CH}_{2} \mathrm{Cl}_{2}$; however, the
ロモプロピオニトリルから行ったが、強い塩基性条件による retro-Micheal 反応で $\mathbf{2 5}$ からシアノエチル残基が $\beta$ - 脱離した 24 が回収された (表 III)。24 の選択的な4-O-シアノエチル化 は酸化銀を用いて 3-ブロモプロピオニトリルと行い 4-O-シア ノエチル体 25 が得られた。興味あることに、24にアクリロニ トリルと DBU を作用させると反応は順調に進み 25 が得られ た。28 の合成のために、24の 4-O-シアノプロピル化は 水素 化ナトリウム存在下、24 と 4-ブロモブチロニトリルを用いて 行い 4-O-シアノプロピル誘導体 $\mathbf{2 6}$ が得られた。また、4-ブ ロモブチロニトリルと酸化銀では $\mathbf{2 6}$ が得られた。

25 と 26 の C-4 位のチオカルバモイルアルキル化は チ才 酢酸 - ピリジンによる文献の方法 (18) で行ったが、反応は進ま なかった。次に、25 と 26 を脱保護し、アセチル化してシア ノアルキル体 29 と 30 とした(スキーム5)。

29 と 30 のシアノアルキル基のチオカルバモイル基への変 換のために、チオ酢酸およびピリジンを使って 29 と 30 のチ オカルバモイル化を行ったが反応は進まなかった（表 IV、en- 


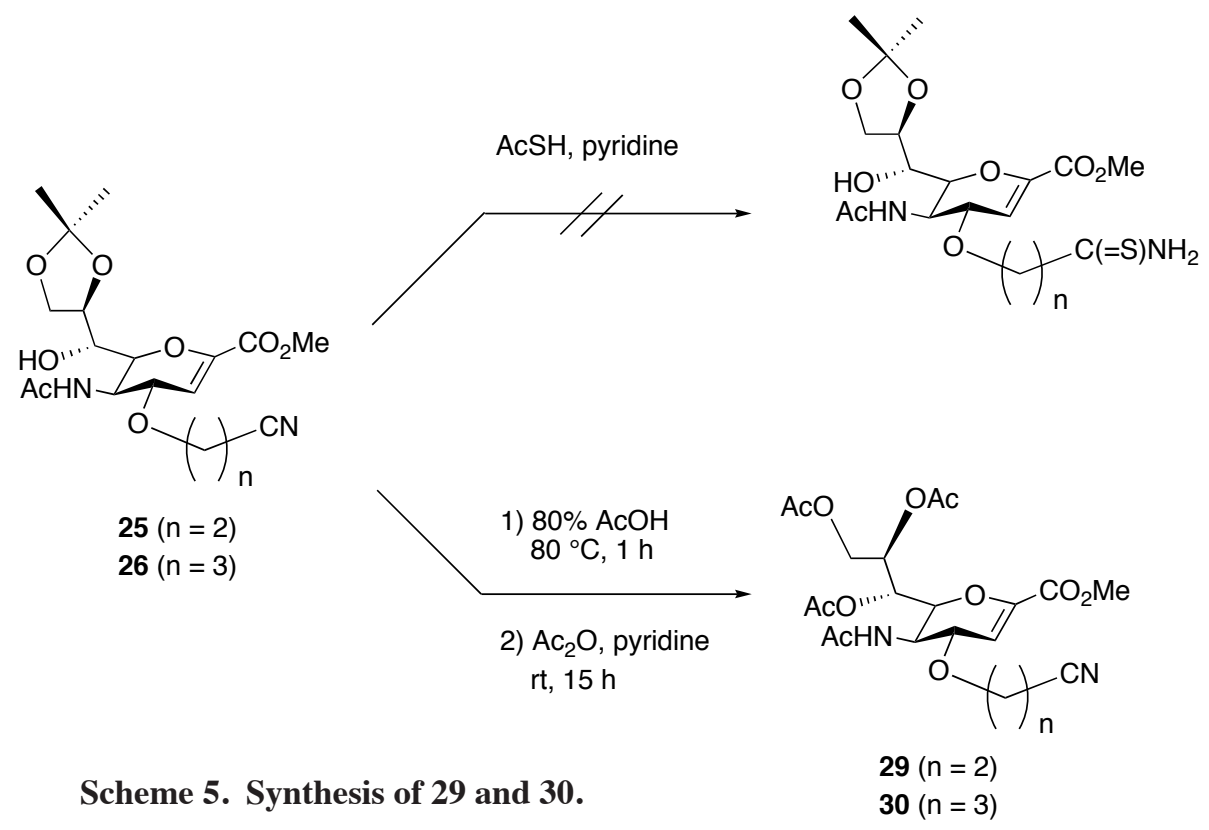

reaction did not proceed (Table IV, entries 1 and 5). Treatment of 29 with AcSH-trimethylsilyl chloride in $\mathrm{CH}_{2} \mathrm{Cl}_{2}$ resulted in recovery of $\mathbf{2 9}$ (entry 3). Thiocarbamoylation of $\mathbf{2 9}$ with $\mathrm{AcSH}_{-} \mathrm{BnNH}_{2}$ gave $\mathbf{3 1}$ in $33 \%$ yield (entry 4 ). When using $\mathrm{BF}_{3} \cdot \mathrm{OEt}_{2}$ instead of pyridine, the reaction gave the expected compound 32 , in contrast to the result of entry 5 (entry 6).

Hydrolysis of $\mathbf{3 2}$ resulted in the expected compound 28; however, hydrolysis of $\mathbf{3 1}$ led to elimination of the tries 1 and 5)。29をチオ酢酸 - トリメチルシリルクロリドで処 理したが原料回収であった (entry 3)。29 のチオカルバモイル 化はチオ酢酸およびブチルアミンを用いることにより 31 が収 率33\%で得られた (entry 4)。Entry 5 の結果とは異なり、ピ リジンの代わりに $\mathrm{BF}_{3} \cdot \mathrm{OEt}_{2}$ を用いることにより期待通り 32 が得られた (entry 6)。

32 の加水分解では予想通り 28 が得られたが、31の場合 は塩基性条件で 4-O-チオカルバモイルエチル部分が脱離した

\section{Table IV. Synthesis of 31 and 32.}

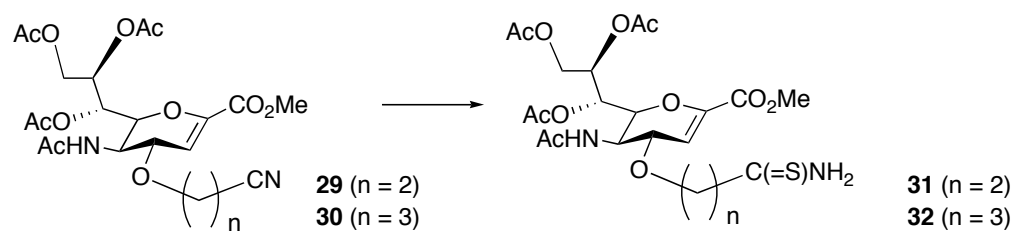

\begin{tabular}{|c|c|c|c|c|}
\hline Entry & Substrate & Conditions & Product & Yield (\%) \\
\hline 1 & 29 & AcSH, pyridine, $\mathrm{CH}_{2} \mathrm{Cl}_{2}, 12 \mathrm{~h}$ & 31 & N.R. ${ }^{a}$ \\
\hline 2 & 29 & $\mathrm{AcSH}, \mathrm{BF}_{3} \mathrm{OEt}_{2}, \mathrm{CH}_{2} \mathrm{Cl}_{2}, 12 \mathrm{~h}$ & 31 & N.R. \\
\hline 3 & 29 & $\mathrm{AcSH}, \mathrm{TMSCl}, \mathrm{CH}_{2} \mathrm{Cl}_{2}, 12 \mathrm{~h}$ & 31 & N.R. \\
\hline 4 & 29 & $\mathrm{AcSH}, \mathrm{BnNH}_{2}, 48 \mathrm{~h}$ & 31 & 33 \\
\hline 5 & 30 & AcSH, pyridine, $\mathrm{CH}_{2} \mathrm{Cl}_{2}, 12 \mathrm{~h}$ & 32 & N.R. \\
\hline 6 & 30 & $\mathrm{AcSH}, \mathrm{BF}_{3} \mathrm{OEt}_{2}, \mathrm{CH}_{2} \mathrm{Cl}_{2}, 12 \mathrm{~h}$ & 32 & 63 \\
\hline
\end{tabular}

a No reaction. 

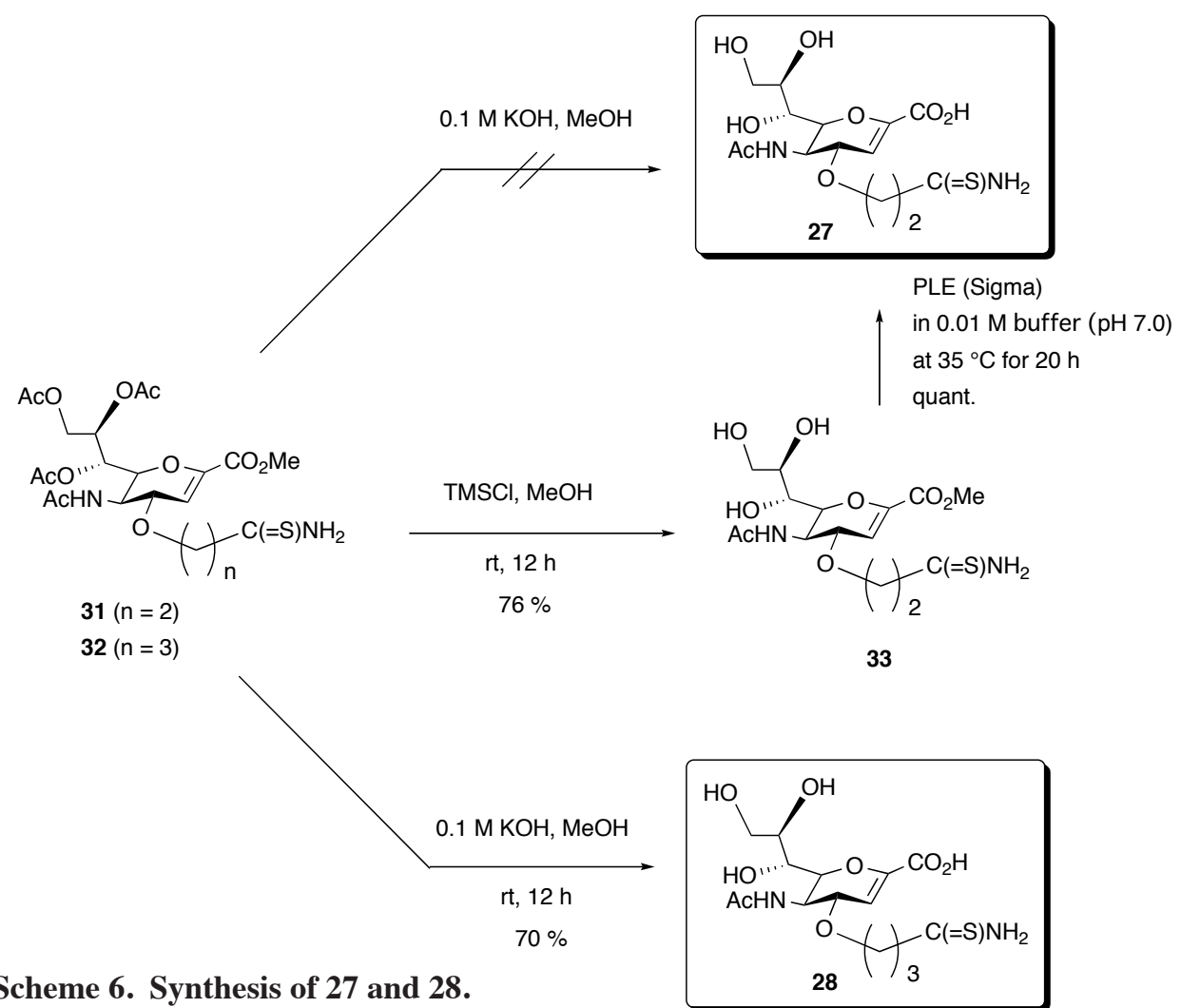

Scheme 6. Synthesis of 27 and 28.

4-O-thiocarbamoylethyl moiety to give $\mathbf{2}$ under strongly basic conditions. Therefore, we focused on searching for an efficient method conducted under mild conditions to hydrolyze the methyl ester residue of $\mathbf{3 1}$ without eliminating the 4-O-thiocarbamoylethyl moiety. We examined enzymatic hydrolysis of the methyl ester group of $\mathbf{3 1}$ using pig liver esterase (PLE) in neutral aqueous conditions. Thus, deprotection of acetyl groups of $\mathbf{3 1}$ with trimethylsilyl chloride in $\mathrm{MeOH}$ was performed to generate 33. Hydrolysis of $\mathbf{3 3}$ with PLE readily produced $\mathbf{2 7}$ in quantitative yield (Scheme 6).

As can be seen in Table V, 4- $O$-thiocarbamoylethyl27 and 4- $O$-thiocarbamoylpropyl-Neu5 Ac 28 have IC $_{50}$ values of $68 \mu \mathrm{M}$ and $102 \mu \mathrm{M}$, respectively. However, the degrees of inhibition of both $\mathbf{2 7}$ and $\mathbf{2 8}$ were lower toward hPIV-1 sialidase than 4-O-thiocarbamoylmethyl-Neu5Ac 9d
2 が回収された。次に、4-O-チオカルバモイルエチル部分の脱 離を伴わない緩和な条件での 31 のメチルエステル基の加水分 解反応を検討した。中性水溶液中での pig liver esterase (PLE) による酵素的な 31 のエステル基の加水分解を検討した。まず、 メタノール中、トリメチルシリルクロリドを用いて 31 のアセ チル基を除去した。33 と PLEの反応は順調に進み定量的に 27 が得られた (スキーム 6)。

表 V に示したように、4-O-チオカルバモイルエチル - 27 と 4-O-チオカルバモイルプロピル - シアル酸 $\mathbf{2 8}$ の阻害活性は それぞれ $\mathrm{IC}_{50} 68 \mu \mathrm{M}$ と $\mathrm{IC}_{50} 102 \mu \mathrm{M}$ であった。しかし、27 と 28 の両方の阻害活性は 4-O-チオカルバモイルメチル体 $9 d$ d $\left(\mathrm{IC}_{50}\right.$

Table V. Inhibitory activities against hPIV-1 sialidase.

\begin{tabular}{ccc}
\hline Entry & Compound & $\mathrm{IC}_{50}(\mu \mathrm{M})$ \\
\hline 1 & $\mathbf{2}$ & 300 \\
2 & $\mathbf{9 d}$ & 10 \\
3 & $\mathbf{2 7}$ & 68 \\
4 & $\mathbf{2 8}$ & 102 \\
\hline
\end{tabular}


$\left(\mathrm{IC}_{50} 10 \mu \mathrm{M}\right)$. The reason for this lower inhibitory activity of compounds 27 and 28 is unclear in this study, but the difference in carbon chain length of the substituent on the hydroxyl group at the C-4 position of $\mathbf{2}$ may affect inhibitory activities against hPIV-1 sialidase.

\section{E. 4-O-Alkyl-2-Deoxy-2,3-Didehydro-Neu5Ac2en Analogs}

We synthesized a series of 4-O-alkylated Neu5Ac2en derivatives and tested their ability to inhibit hPIV-1 sialidase (19). Selective 4- $O$ alkylation of $\mathbf{2 4}$ with methyl iodide in the presence of silver oxide gave one major product, 4-O-methyl derivative 34a (TableVI, entry 1). Using a similar method, 4- $O$ alkylation of $\mathbf{2 4}$ with alkyl bromides in the presence of silver oxide gave 34b-d (entries 2-4); however, the reaction of 24 with propargyl bromide in the presence of silver oxide was unsuccessful (entry 6). Reactions of $\mathbf{2 4}$ with allyl bromide and propargyl bromide using sodium hydride as a base successfully gave $\mathbf{3 4 e}$ and $\mathbf{3 4 f}$ (entries 7 and 8).

Deprotection of 34a-f gave 35a-f (Table VII). Interestingly, 4-O-ethyl-Neu5Ac2en 35b (20) showed the most potent inhibitory activity ( IC $_{50} 6.3 \mu \mathrm{M}$ ) (Table VII). The degree of inhibition was the same as that of 9d. Additionally, compound 35d exhibited decreased sialidase inhibition compared with $35 b$ and $\mathbf{3 5 c}$, indicating that increasing the alkyl substituent size influences inhibitory activity. These results suggest that the substituent bulkiness at the C-4 alcohol of 2 affect interaction with the cavity. It is also possible that hPIV-1 has an area of hydrophobic interaction with the C-4 position of $\mathbf{2}$ in the cavity of the catalytic pocket in HN glycoprotein.

Table VI. 4-O-Alkylation of 24.
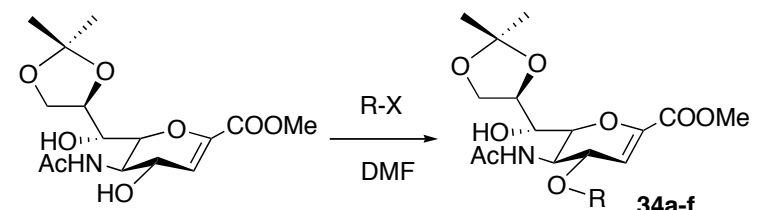

24

\begin{tabular}{cllcc}
\hline Entry & $\mathrm{R}-\mathrm{X}$ & Condition & Product & Yield (\%) \\
\hline 1 & $\mathrm{Mel}$ & $\mathrm{Ag}_{2} \mathrm{O}, \mathrm{TBAl}$ & $\mathbf{3 4 a}$ & 56 \\
2 & $\mathrm{EtBr}$ & $\mathrm{Ag}_{2} \mathrm{O}, \mathrm{TBAl}$ & $\mathbf{3 4 b}$ & 45 \\
3 & $\mathrm{n}-\mathrm{PrBr}$ & $\mathrm{Ag}_{2} \mathrm{O}, \mathrm{TBAl}$ & $\mathbf{3 4 c}$ & 41 \\
4 & $i-\mathrm{PrBr}$ & $\mathrm{Ag}_{2} \mathrm{O}, \mathrm{TBAl}$ & $\mathbf{3 4 d}$ & 25 \\
5 & allyl bromide & $\mathrm{Ag}_{2} \mathrm{O}, \mathrm{TBAl}$ & $\mathbf{3 4 e}$ & 69 \\
6 & propargyl bromide & $\mathrm{Ag}_{2} \mathrm{O}, \mathrm{TBAl}$ & $\mathbf{3 4 f}$ & $\mathrm{N} \cdot \mathbf{R}^{\mathrm{a}}$ \\
7 & allyl bromide & $\mathrm{NaH}$ & $\mathbf{3 4 e}$ & 52 \\
8 & propargyl bromide & $\mathrm{NaH}$ & $\mathbf{3 4 f}$ & 56 \\
\hline
\end{tabular}

a No reaction.
$10 \mu \mathrm{M})$ よりも弱かった。27 と 28 の阻害活性が 9d に比べて低 かった理由は不明であるが、2 の C-4 位の水酸基の置換基の炭 素鎖長の相違が hPIV-1 シアリダーゼに対する阻害活性に影響 を与えることが明らかとなった。

E. 4-O- アルキル -2- デオキシ -2,3- デヒドロ - シアル酸誘導体

この項では、4-O-アルキル化シアル酸誘導体の合成と hPIV-1 シアリダーゼに対する阻害活性について述べる (19)。 選択的な 24 の 4-O-アルキル化を酸化銀の存在下、ヨウ化メチ ルと行い主生成物として 4-O-メチル体 34a を得ることができ た（表 VI, entry 1)。

同様に、24 の 4-O-アルキル化を酸化銀の存在下、種々 のアルキルブロミドと行い 34b-d を合成することができたが (entries 2, 3, and 4)、24 とプロパルギルブロミドとの反応は酸 化銀では進まなかった (entry 6)。24 とアリルブロミドとプロ パルギルブロミドとの反応は塩基として水素化ナトリウムを 用いることにより 34e と 34f がそれぞれ順調に得られた (entries 7 and 8)。34a-f を脱保護し 35a-f とした（表 VII）。

興味あることに、4-O-エチルシアル酸誘導体 $\mathbf{3 5 b}(20)$ が最 も強い阻害活性を示した $\left(\mathrm{IC}_{50} 6.3 \mu \mathrm{M}\right)$ 。その阻害活性は 9d と 同程度であった。一方、化合物 35d では、活性に影響を及ぼ すアルキル基の大きさの増大に伴い $35 \mathrm{~d} や 35 \mathrm{c}$ と比べて阻害 活性が減弱した。これらの結果は、2 の C-4 位水酸基上の置 換基のかさ高さが触媒部位の空洞との相互作用に影響を与え ていることが示された。hPIV-1 の HN の触媒部位の空洞は、 2 の C-4 位と疎水的な相互作用する部分をもっている可能性 も考えられる。

Table VII. Synthesis and inhibitory activities of 35a-f against hPIV-1 sialidase.

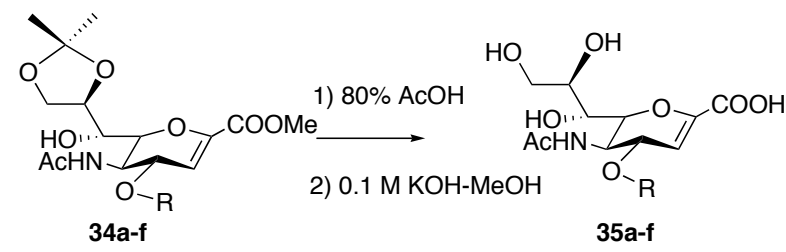

\begin{tabular}{ccccc}
\hline Entry & $\mathrm{R}$ & Product & Yield $(\%)$ & $\mathrm{IC}_{50}(\mu \mathrm{M})$ \\
\hline 1 & $\mathrm{Me}$ & $\mathbf{3 5 a}$ & quant. & 274 \\
2 & $\mathrm{Et}$ & $\mathbf{3 5 b}$ & 59 & 6.3 \\
3 & $n-\mathrm{Pr}$ & $\mathbf{3 5 c}$ & 85 & 26 \\
4 & $i-\mathrm{Pr}$ & $\mathbf{3 5 d}$ & 43 & 58 \\
5 & $\mathrm{CH}_{2} \mathrm{CH}=\mathrm{CH} \mathrm{CH}_{2}$ & $\mathbf{3 5 e}$ & 81 & 83 \\
6 & $\mathrm{CH}_{2} \mathrm{C} \equiv \mathrm{CH}$ & $\mathbf{3 5 f}$ & 97 & 29 \\
\hline
\end{tabular}




\section{F. 4-O-(3-Heteroaryl-2-Proynyl)-2-Deoxy-2,3-Didehydro- Neu5Ac2en Analogs}

We focused on synthesis of a novel Neu5Ac2en $\mathbf{3 6}$ (21) containing heterocycles primarily using the Sonogashira coupling reaction (22). We anticipated that the 4-hydroxy group configuration of $\mathbf{2}$ may play a substantial role in inhibition of sialidase by hPIV-1. Therefore, to gain further insight into the interaction of sialidase with the substituent at C-4 on Neu5Ac2en derivatives, we synthesized 4-epiNeu5Ac2en derivative $\mathbf{3 7}$ modified at the C-4 of $\mathbf{2}$. We initially focused on the synthesis of $\mathbf{3 6}$ using a Sonogashira coupling reaction starting from the 4-O-2-propynyl-Neu5Ac2en derivative 34f (Scheme 7).
F. 4-O-(3-ヘテロアリール -2- プロピニル )-2- デオキシ -2,3デヒドロ - シアル酸誘導体

この項では、薗頭カップリング反応 $(\mathbf{2 1})$ を鍵反応としたへ テロ環部分を持つ 36 の合成について述べる $(22)$ 。2 の 4 位水 酸基の立体配置が hPIV-1 シアリダーゼの阻害活性に重要な役 割を果たしていると考えられてきた。さらに、Neu5Ac2en 誘 導体の C-4 位の置換基とシアリダーゼとの相互作用を調べる ために、2の C-4 位を修飾した 4-epi- シアル酸誘導体 37 の合 成も行った。最初の研究は、4-O-(2- プロピニル)-シアル酸誘 導体 34f から薗頭カップリング反応による 36 の合成であった (スキーム 7)。
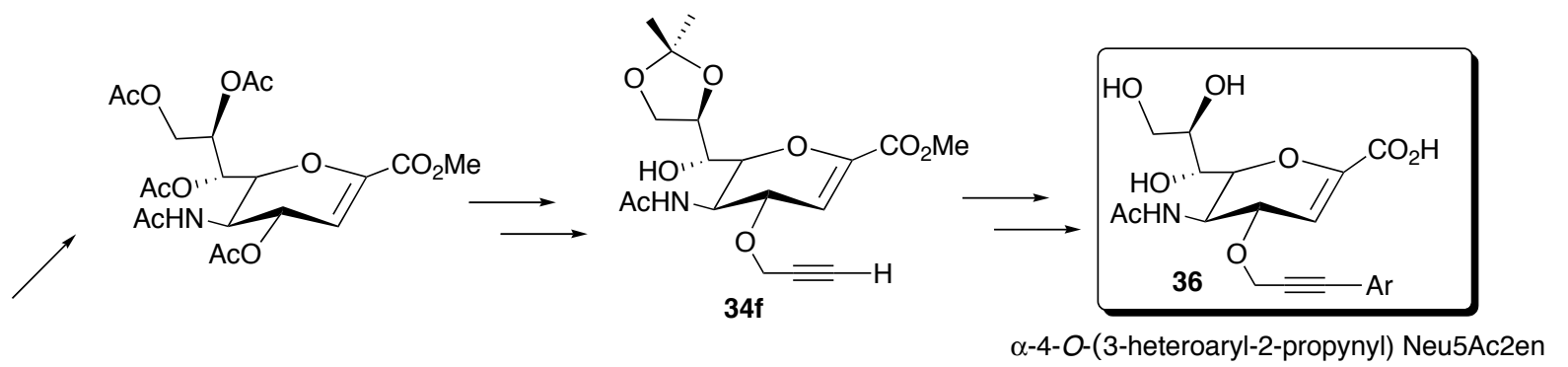

Neu5Ac1Me

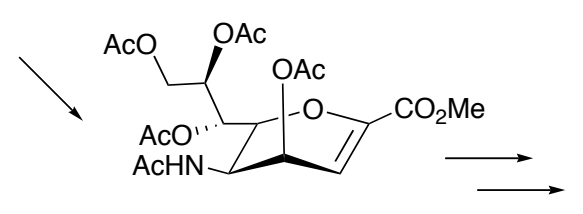

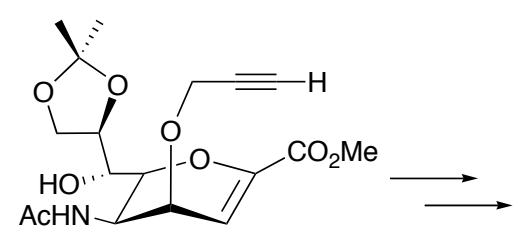

42

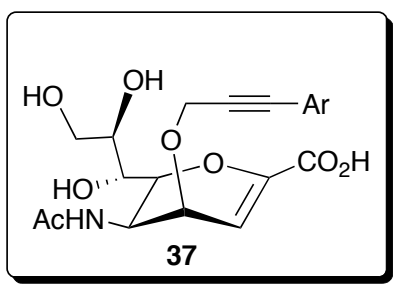

$\beta$-4-O-(3-heteroaryl-2-propynyl) Neu5Ac2en $\mathrm{Ar}=$ heteroaryl groups

Scheme 7. Synthesis of 4-O-(3-heteroaryl-2-propynyl) Neu5Ac2en derivatives.

Sonogashira coupling reactions were performed under the conditions in method A (23) (Table VIII). When iodobenzene was used as an aryl halide, the corresponding product 38a was obtained (entry 1). When 2-iodopyridine, 3-iodopyridine, and 2-iodothiophene were used as heteroaryl halides under the same conditions, products $\mathbf{3 8 b}$-d were obtained, respectively (entries 2, 3, and 4). However, the coupling reaction of $\mathbf{3 4 \mathbf { f }}$ with 3 -bromothiophene led to recovery of $\mathbf{3 4 f}$ under the conditions in method A (entry 5). The reaction of $\mathbf{3 4} \mathbf{f}$ with bromothiophene under the conditions in method B (24) as an alternative procedure gave poor yield of 38e (entry 6). When iodothiophene and method A were combined, 38e was obtained (entry 7). In sharp contrast with the result of entry 8 , the coupling reaction of $\mathbf{3 4 f}$ with 2-bromo-1,3-thiazole under the conditions in method B generated $\mathbf{3 8 f}$ (entry 9). For the synthesis of $\mathbf{3 8 g}$-j with an additional substitution on the heteroaryl 5-membered ring, compound 34f successfully underwent a Sonogashira coupling reaction with heteroaryl halides under the conditions in method A to generate $\mathbf{3 8 g}$-j.
薗頭カップリング反応は条件 A (23) ( 表 VIII) を用いて 行った。アリールハライドとしてヨードベンゼンを用いたと きには、対応する38a が得られた（entry 1)。2-ヨードピリジ ン、3-ヨードピリジン、2-ヨードチオフェンをへテロアリー ルハライドとして用い、条件 A で反応を行ったとき $\mathbf{3 8 b - d}$ が それぞれ得られた（entries 2, 3, and 4)。しかし、34f と 3-ブ ロモチオフェンを条件 A で行った場合には 34f が回収された (entry 5)。別法として条件 B (24) で34f と 3-ブロモチオフェ ンとの反応を行うと低收率ながら 38e が得られた（entry 6)。 3-ヨードチオフェンと条件 A で反応を行うと、38e が順調に 得られた (entry 7)。Entry 8 の結果と対照的に、34f と2-ブ ロモ-1,3-チアゾールとの反応を条件 B で行うと $38 f$ を得るこ とができた（entry 9)。ヘテロアリールの 5 員環上に置換基を もつ 38g-j の合成は、34f とへテロアリールハライドとの反応 を条件 Aにより行い 38g-j が得られた。 
Table VIII. Synthesis of 38 by the Sonogashira coupling reaction.
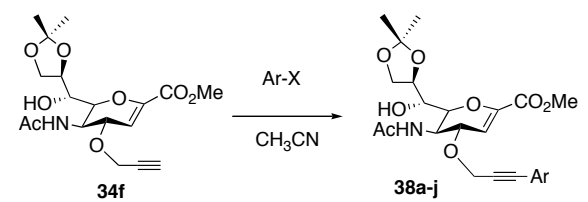

\begin{tabular}{llll}
\hline Entry & Ar-X & Condition $^{\mathrm{a}}$ & Yield (\%) \\
\hline
\end{tabular}

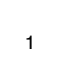

1

2

3

4

5

6

7

8

9

10

约

(1)

, से

Br $|\mathrm{S}\rangle$

$\mathrm{Br}$

8

10

112

12

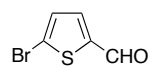

13

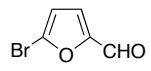

$38 a(53)$
A

A

A

A

B

A

A

B

A

A

A

A

$38 b(73)$

38c (93)

38d (83)

N.R.

38e (trace)

38e (76)

N.R.

38f (59)

$38 \mathrm{~g}(92)$

$38 \mathrm{~h}(55)$

38i (62)

38j (49)
Table IX. Synthesis and Inhibitory activities of 36a-j against hPIV-1 sialidase.

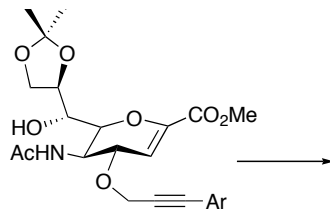

38

\begin{tabular}{|c|c|c|c|c|}
\hline Entry & Ar & Yield of $39(\%)$ & Yield of $36(\%)$ & $\mathrm{IC}_{50}(\mu \mathrm{M})$ \\
\hline 1 & & $392(80)$ & $369(83)$ & 15 \\
\hline
\end{tabular}

2

$\overbrace{N}$

39b (91)

36b (quant.) $)^{a} \quad 14$<smiles>Cc1cccnc1</smiles>

$39 c(83)$

36c (quant.) $)^{a} \quad 88$

$\lambda_{S}$

39d (98)

$36 d(66)$

1.2<smiles></smiles>

39 e (89)

$36 e(76)$

2.5

$39 f(83)$

3.1

39h (95) 36h (98) $\quad 250$

8

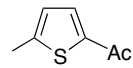

$39 i(80)$

36i (96)

230

39j (89)

36j (46)

60

A] RX (1.1 eq.), $\mathrm{Pd}\left(\mathrm{PPh}_{3}\right)_{2} \mathrm{Cl}_{2}$ (2 mol\%), Cul (4 mol\%), $\mathrm{Et}_{3} \mathrm{~N}$ (3 eq.).

B] RX (1.1 eq.), $\mathrm{Pd}\left(\mathrm{CH}_{3} \mathrm{CN}\right)_{2} \mathrm{Cl}_{2}(5 \mathrm{~mol} \%), \mathrm{Cu}(\mathrm{OAc})_{2} \cdot \mathrm{H}_{2} \mathrm{O}(5 \mathrm{~mol} \%), \mathrm{PPh}_{3}(10 \mathrm{~mol} \%)$,

i- $\mathrm{Pr}_{2} \mathrm{NH}(2 \mathrm{~mL})$

No reaction.

Deprotection of 38a-j, except for $\mathbf{3 8 g}$, gave the target compounds 39a-f and $\mathbf{3 9 h}-\mathbf{j}$ (Table IX). In the production of $\mathbf{3 8 g}$, starting material decomposition occurred with the treatment under acidic conditions.

We were interested in comparing inhibitory activities of $\mathbf{3 6}$ and 4-epimer $\mathbf{3 7}$ of $\mathbf{3 6}$ against hPIV-1 sialidase. As outlined in scheme 8 , synthesis of compound $\mathbf{4 2}$ as an intermediate was achieved using the known compound $\mathbf{4 0}$ (25). Installation of a propargyl group at the 4-hydroxyl group of 41 using sodium hydride and propargyl bromide gave intermediate $\mathbf{4 2}$.

Synthesis of 43a-c was performed using a Sonogashira coupling reaction in a manner similar to the preparation of $\mathbf{3 6}$. The results are summarized in Table X.Deprotection of 43a-c
$38 \mathrm{~g}$ を除く 38a-j の脱保護により 39a-f と 39h-j が得られた (表 IX)。38g の場合には、酸性条件で出発原料が分解した。

36 とその 4- エピマー体 37 の hPIV-1 シアリダーゼに対す る阻害活性を比較することに興味が持たれた。スキーム 8 に 示したように、鍵化合物 $\mathbf{4 2}$ の合成は既知化合物 40(24) から行っ た。41の 4 位水酸基へのプロバギル基の導入は水素化ナトリ ウムとプロパルギルブロミドを用いて行い、鍵化合物 42 とし た。

43a-c の合成は 38 の合成と同様の条件で溒頭カップリン グ反応を行った。結果は、表 Xに示した。連続した43a-c の 


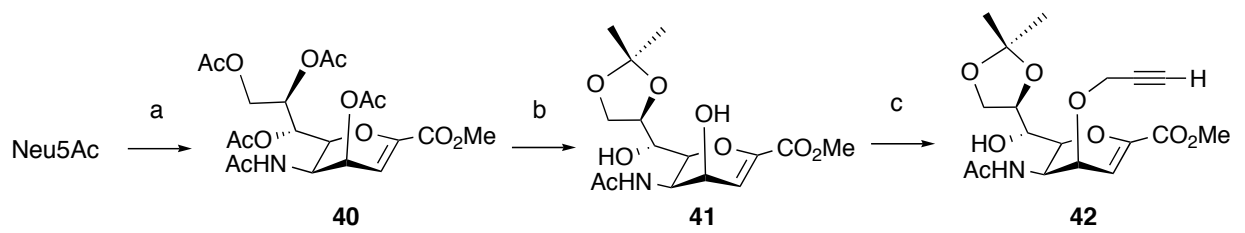

Scheme 8. Reagents and conditions. (a) (i) $\mathrm{MeOH}$, Amberlite IR120 ( $\mathrm{H}^{+}$), rt, $15 \mathrm{~h}$, quant., (ii) $\mathrm{Ac}_{2} \mathrm{O}$, $\mathrm{H}_{2} \mathrm{SO}_{4}, 80{ }^{\circ} \mathrm{C}, 3 \mathrm{~h}, 96 \%$ ( $4 \alpha: 4 \beta=1: 8$ ); (b) (i) $\mathrm{NaOMe}, \mathrm{MeOH}, 0{ }^{\circ} \mathrm{C}, 1 \mathrm{~h}$, quant; (ii) 2,2-dimethoxypropane, DMF, Amberlite IR120 $\left(\mathrm{H}^{+}\right)$, rt, 12 h, 58\%; (c) propargyl bromide, $\mathrm{NaH}, \mathrm{DMF}, 0{ }^{\circ} \mathrm{C}, 1 \mathrm{~h}, 39 \%$.

Table X. Synthesis of 43 by the Sonogashira coupling reaction afforded compounds 37a-c, respectively.

\begin{tabular}{|c|c|c|c|c|}
\hline & 42 & $\mathrm{CH}_{3} \mathrm{CN}$ & 43 & \\
\hline Entry & Ar-X & Conditiona & Product & Yield (\%) \\
\hline 1 & & A & $43 a$ & 64 \\
\hline 2 & & A & $43 b$ & 73 \\
\hline 3 & & B & $43 \mathrm{c}$ & 48 \\
\hline
\end{tabular}

a Method A: RX (1.1 eq.), $\mathrm{Pd}\left(\mathrm{PPh}_{3}\right)_{2} \mathrm{Cl}_{2}$ (2 mol\%), Cul (4 mol\%), $\mathrm{Et}_{3} \mathrm{~N}$ (3 eq.).

Method B: RX (1.1 eq.), $\mathrm{Pd}\left(\mathrm{CH}_{3} \mathrm{CN}\right)_{2} \mathrm{Cl}_{2}(5 \mathrm{~mol} \%), \mathrm{Cu}(\mathrm{OAc})_{2} \cdot \mathrm{H}_{2} \mathrm{O}(5 \mathrm{~mol} \%)$

$\mathrm{PPh}_{3}(10 \mathrm{~mol} \%), i-\mathrm{Pr}_{2} \mathrm{NH}(2 \mathrm{~mL})$.
As seen in Table IX, 2-thienyl-Neu5Ac2en 36d had a strong inhibitory effect $\left(\mathrm{IC}_{50} 1.2 \mu \mathrm{M}\right)$ on hPIV-1 sialidase. Furthermore, compounds 36e and 36f had nearly the same inhibitory effects. In contrast, compound 37a-c, the 4-epimer of 36, inhibited sialidase much less than $\mathbf{3 6}$, and compound 37c was not effective against sialidase. These results demonstrate that side chain stereochemistry and conformation

\section{脱保護により 37a-c とした（表 XI）。}

表 IXに示したように、興味あることに、2-チエニル - シ アル酸誘導体 36d が hPIV-1 シアリダーゼに最も強い阻害活性 $\left(\mathrm{IC}_{50} 1.2 \mu \mathrm{M}\right)$ を示した。さらに、化合物 36e と 36f はほぼ同じ 阻害活性を持っていた。これに対して、36の 4-エピマー体で ある37a-c は、36 と比較して阻害活性はかなり弱く、37c はシ

Table XI. Synthesis and inhibitory activities of 37 .

\begin{tabular}{|c|c|c|c|c|}
\hline 43 & & $\left.\right|_{44 a-c} ^{\mathrm{OH}}$ & 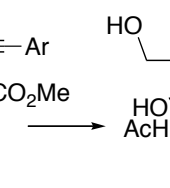 & $\underbrace{O H}_{37 a-c}$ \\
\hline Entry & Ar & Yield of $44(\%)$ & Yield of $\mathbf{3 7}(\%)$ & $\mathrm{IC}_{50}(\mathrm{mM})$ \\
\hline 1 & & 44a (68) & $37 a(60)$ & 1.1 \\
\hline 2 & & $44 b(79)$ & 37b (99) & 1.7 \\
\hline 3 & & $44 c(53)$ & $37 c(94)$ & 1.3 \\
\hline
\end{tabular}


have a dominating influence over the interaction of unsaturated sialic acids with the enzyme. This in silico procedure suggests that the origin of the strong binding affinity of $\mathbf{3 6 \mathbf { d }}$ may be caused by $\mathrm{CH}-\pi$ type interactions of the thienyl residue at 4-OH group of $\mathbf{2}$ with enzyme.

\section{G. 4- $O$ - $N$-Sulfonylamidinoalkyl-2-Deoxy-2,3-Didehydro- Neu5Ac2en Analogs}

Multicomponent reactions (MCRs), a straightforward route to generate complexity and diversity in a single step, have become important tools in the combinatorial and pharmaceutical chemistry (25). Amidines are prominent pharmacophores present in numerous bioactive natural products (26). The introduction of a sulfonyl group into a wide range of heterocyclic compounds results in significant changes in the bioactivity of these compounds (27). There are no reports regarding the synthesis of a Neu5Ac2en analog with an $N$-sulfonylamidino group (46) at the C-4 position of $\mathbf{2}$ using copper-catalyzed three-component coupling of sulfonyl azide, alkyne, and amine. We describe the synthesis of a novel compound 46 with an $N$-sulfonylamidino group at the C-4 position of 2 using the three-component coupling reaction (28) (Scheme 9).
アリダーゼに有効ではなかった。これらの結果は、側鎖の立 体配置や立体配座は酵素と不飽和シアル酸との相互作用を支 配していることを示している。36d の高い阻害活性は 2 の 4 位 水酸基上のチエニル残基と酵素との $\mathrm{CH}-\pi$ 相互作用に起因し ていることが in silico 法により示唆された。

G. 4-O-N-スルホニルアミジノアルキル -2- デオキシ -2,3- デ ヒドロ - シアル酸誘導体

Multicomponent reactions (MCRs) は、一回の操作で複雑 さや多様性を化合物に付与できることから、コンビナトリア ルケミストリーや医薬品合成化学において重要な合成手法と なっている (25)。アミジンは、多彩な生物活性を持つ天然物の 重要なファーマコフォアーある (26)。さらに、広範なへテロ環 化合物へのスルホニル基の導入は、化合物の生物活性に大き

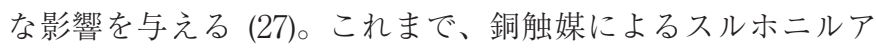
ジド、アルキン、アミンの三成分結合反応による 2 のC-4 位 に $N$-スルホニルアミジノ基を持つ Neu5Ac2en 誘導体 46 の合 成は知られていない。この項では、三成分結合反応を鍵反応 として用いた 2 の C-4 位に $N$ - スルホニルアミジノ基を持つ 46 の合成について述べる (28)（スキーム 9)。

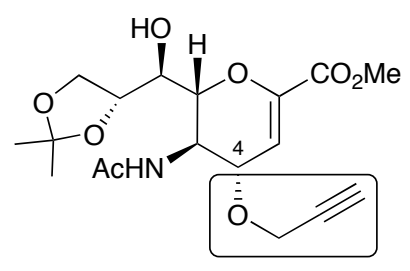

$34 f$
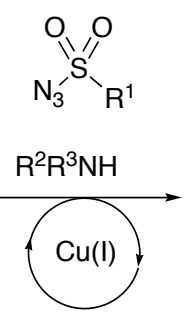

MCRs

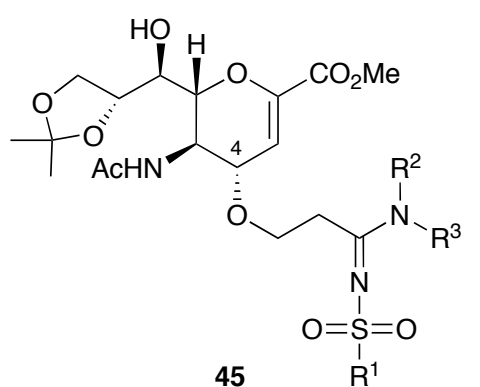

45

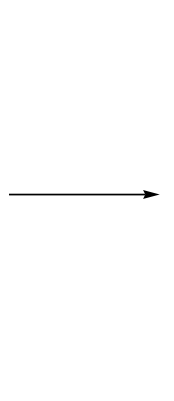

Scheme 9. Synthesis of $N$-sulfonylamidino analogs 46 using MCRs.

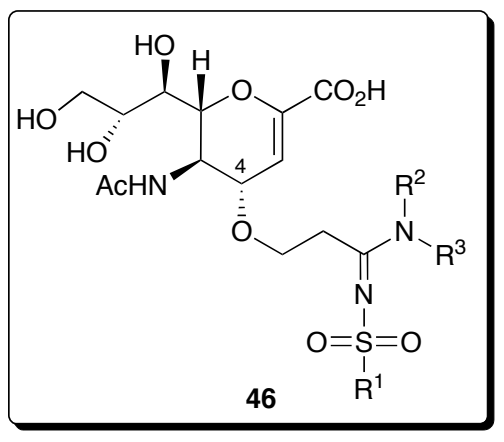

$R^{1}, R^{2}, R^{3}=H$, alkyl, aryl
MCRs were performed using a combination of 4-O-2propynyl-Neu5Ac2en derivative 34f, amines, CuI, and Et3N as listed in Table XII. Under optimized conditions, many 3 -component groups were successfully coupled to afford the corresponding $N$-sulfonylamidines (45a-e) in yields ranging from $60 \%$ to quantitative yield (Table XII).

To synthesize $\mathbf{4 5 f}$ with a primary amino group on the $N$-sulfonylamidino substituent, a coupling reaction of $\mathbf{3 4 f}$ using ammonium chloride gave $\mathbf{4 5 f}$ (Scheme 10).

Deprotection of $\mathbf{4 5 a - e , ~ b u t ~ n o t ~} \mathbf{4 5 f}$, gave the $N$-sulfonylamidino compounds 46a-e (Table XIII).

Among synthesized compounds 46a-e, compound 46b showed the highest activity $\left(\mathrm{IC}_{50} 0.8 \mathrm{mM}\right)$ against hPIV-1 sialidase (Table XIV). However, the degrees of inhibition of both $46 \mathrm{a}$ and $\mathbf{4 6 b}$ were weaker than that of $2\left(\mathrm{IC}_{50} 0.3 \mathrm{mM}\right)$. Compounds 46c-e, with the largest hydrophobic groups,
表XIIに示したように、MCR は 4-O-(2-プロピニル )- シ アル酸誘導体 34f、アミン、ヨウ化銅 (I)、トリエチルアミンと の組み合わせにより行った。最適条件下で多彩な三成分結合 反応が順調に進み対応する $N$ - スルホニルアミジン体 45a-g が 60\%～定量的な収率で得られた（表 XII）。

$N$ - スルホニルアミジンの置換基上に第一級アミノ基を持 つ 45f の合成には、34f と塩化アンモニウムを用いて行った（ス キーム 10)。

45f を除いた 45a-e の脱保護により、 $N$ - スルホニルアミジ ン化合物 46a-e が得られた（表 XIII）。

46a-e の中で、46b が hPIV-1 シアリダーゼに最も強い阻 害活性 $\left(\mathrm{IC}_{50}=0.8 \mathrm{mM}\right)$ を示した (表 XIV)。しかし、46a や 46b はともに $2\left(\mathrm{IC}_{50}=0.3 \mathrm{mM}\right)$ よりも弱かった。最も大きな 疎水性基を持つ 46c-e は 46a や 46b に比べて阻害活性は減少 
Table XII. Synthesis of 45a-e by $\mathrm{Cu}(\mathrm{I})$-catalyzed three-component coupling.
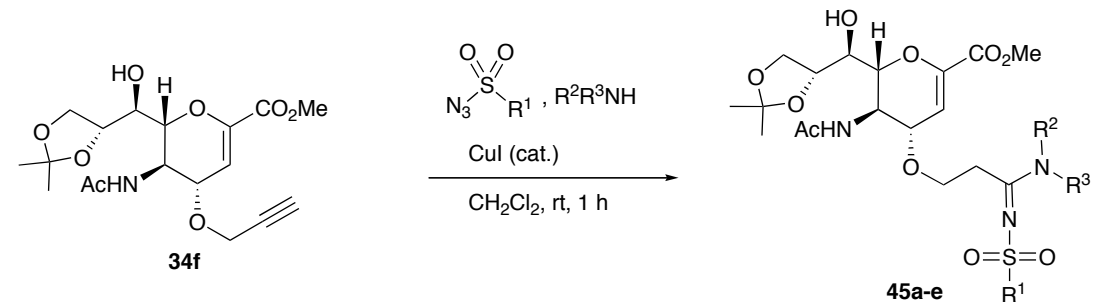

\begin{tabular}{ccccc}
\hline Entry & Azide $\left(\mathrm{R}^{1}\right)$ & Amine $\left(\mathrm{R}^{2} \mathrm{R}^{3} \mathrm{NH}\right)$ & Product & Yield (\%) \\
\hline 1 & $\mathrm{Me}$ & $\mathrm{Et}_{2} \mathrm{NH}$ & $\mathbf{4 5 a}$ & 85 \\
2 & $\mathrm{Me}$ & $\mathrm{PhNH}_{2}$ & $\mathbf{4 5 b}$ & No conversion \\
3 & $\mathrm{Me}$ & $\mathrm{PhNH}_{2}$ & $\mathbf{4 5 b}$ & $60^{\mathrm{b}}$ \\
4 & $4-\mathrm{MeC}_{6} \mathrm{H}_{4}$ & $\mathrm{Et}_{2} \mathrm{NH}$ & $\mathbf{4 5 c}$ & 80 \\
5 & $4-\mathrm{MeC}_{6} \mathrm{H}_{4}$ & $i-\mathrm{Pr}_{2} \mathrm{NH}$ & $\mathbf{4 5 d}$ & quant. \\
6 & $4-\mathrm{MeC}_{6} \mathrm{H}_{4}$ & $i-\mathrm{PrNH}_{2}$ & $45 \mathbf{e}$ & 64 \\
\hline
\end{tabular}

a $79 \%$ starting material $\mathbf{3 4 f}$ was recovered.

${ }^{\mathrm{b}} \mathrm{Et}_{3} \mathrm{~N}(1.2 \mathrm{eq})$ was added.

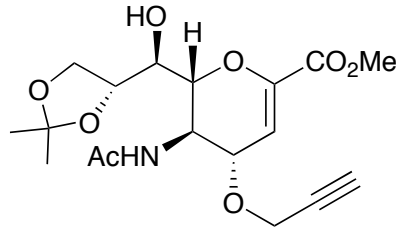

$34 f$

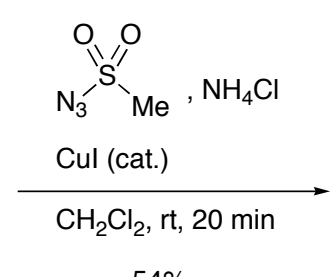

$54 \%$

Scheme 10. Synthesis of $\mathbf{4 5 f}$.

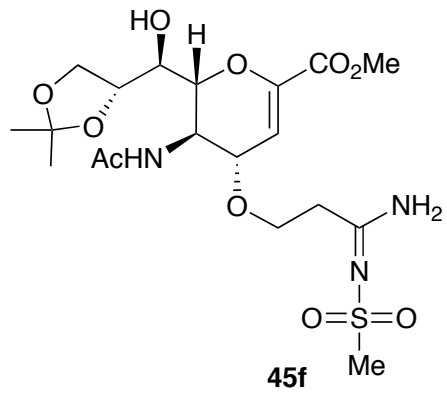

Table XIII. Deprotection of 46a-e.
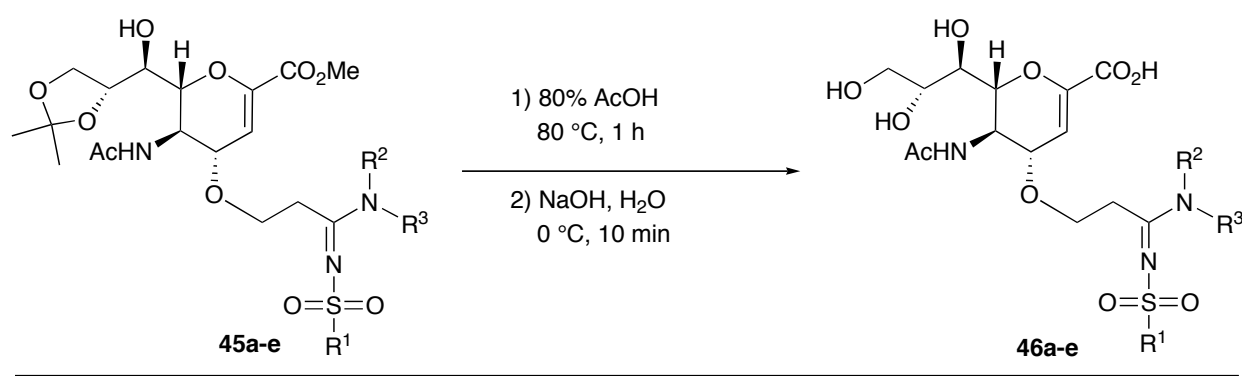

\begin{tabular}{ccccc}
\hline Entry & $\mathrm{R}^{1}$ & $\mathrm{NR}^{2} \mathrm{R}^{3}$ & Product & Yield (\%) \\
\hline 1 & $\mathrm{Me}$ & $\mathrm{NEt}_{2}$ & $\mathbf{4 6 a}$ & quant. \\
2 & $\mathrm{Me}$ & $\mathrm{NHPh}$ & $\mathbf{4 6 b}$ & quant. \\
3 & $4-\mathrm{MeC}_{6} \mathrm{H}_{4}$ & $\mathrm{NEt}_{2}$ & $\mathbf{4 6 c}$ & quant. \\
4 & $4-\mathrm{MeC}_{6} \mathrm{H}_{4}$ & $\mathrm{Ni}^{-\mathrm{Pr}}$ & $\mathbf{4 6 d}$ & 95 \\
5 & $4-\mathrm{MeC}_{6} \mathrm{H}_{4}$ & $\mathrm{NHi-Pr}$ & $\mathbf{4 6 e}$ & quant. \\
\hline
\end{tabular}

showed decreased inhibitions of sialidase compared with $\mathbf{4 6 a}$ and 46b. These studies suggest that diminished activity results from fewer favorable interactions between sialidase inhibitors $\mathbf{4 6}$ with the $\mathrm{N}$-sulfonylamidino group at the $\mathrm{C}-4$ position of $\mathbf{2}$ and the sialidase.
した。これらの研究により、阻害活性の低下は、2 のC-4 位に $N$ - スルホニルアミジノ基を持つ 46 と酵素の相互作用の不適合 にあると推測している。 
Table XIV. Inhibitory activities of 46a-e against hPIV-1 sialidase.

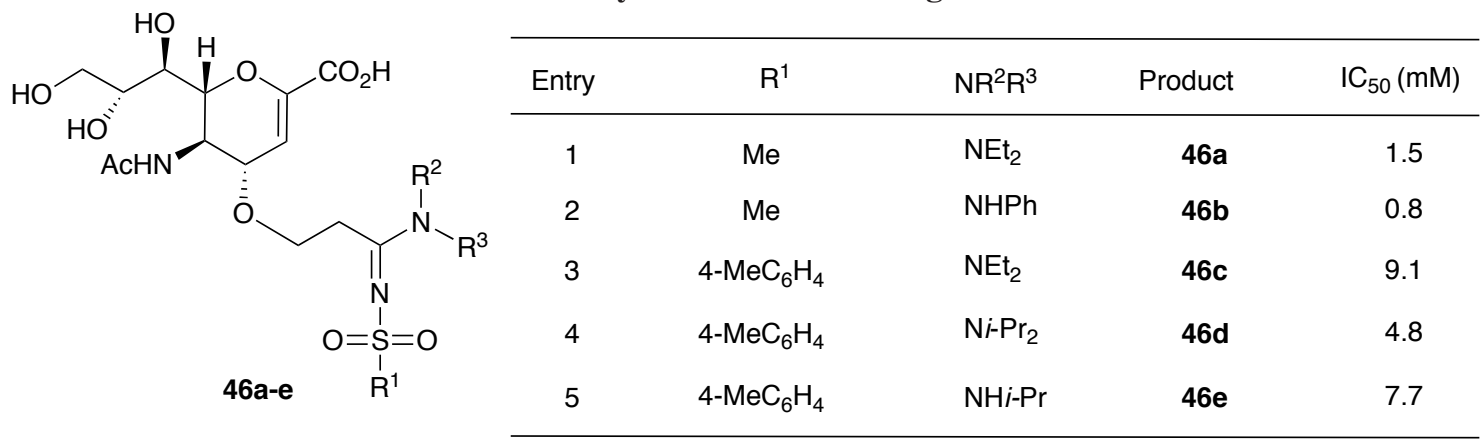

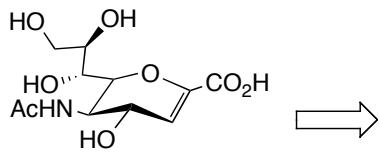

2: $\mathrm{IC}_{50}=0.30 \mathrm{mM}$

\section{Scheme 11. Novel candidates for anti-hPIV-1 agents.}

\section{H. Conclusion}

Structural modification of sialic acids is a useful strategy for evaluating structure-activity relationships for the development of new drug candidates. This article disclosed recent progress, including our own, in the synthesis of 2-deoxy-2,3-didehydro sialic acid analogs and their inhibitory activities against hPIV-1 sialidase. We demonstrated that among compounds modified on the C-4 position of 2 , a new analog, 36d, had the most potent inhibitory activity towards hPIV-1 sialidase (Scheme 11). Inhibition is considerably improved compared with that of the parent 4-hydroxy

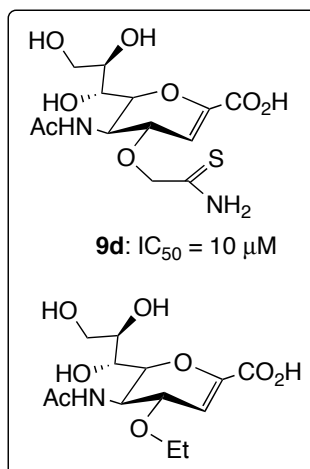

35b: $I_{50}=6.3 \mu \mathrm{M}$

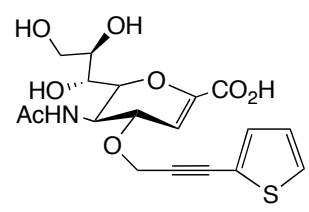

36d: $: C_{50}=1.2 \mu \mathrm{M}$

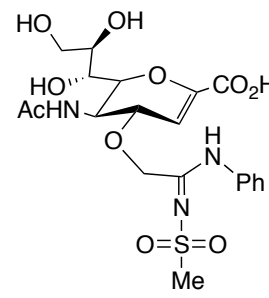

46b: $I C_{50}=0.80 \mathrm{mM}$

\section{H. 結 論}

シアル酸の構造修飾は新しい医薬品候補開発のための構 造活性相関を評価するうえで非常に有用な戦略である。この 総説では、このように hPIV-1 シアリダーゼに対して阻害活性 をもつ 2- デオキシ -2,3- ジデヒドロ - シアル酸誘導体の合成に ついて我々の研究を含む最近の進展を述べた。今回我々は、2 の 4-OH 体を修飾した化合物の中で 36d がこれまでに知られ ている中で最も強い hPIV-1 シアリダーゼ活性をもつことを証 明した（スキーム 11）。この化合物は、母骨格 $4-\mathrm{OH}$ 体 2 と 
compound 2. This suggests that analogs of Neu5Ac2en modified at the C-4 are very useful in the development of antihuman parainfluenza virus medicines.

\section{Acknowledgements}

We would like to express our deep gratitude to emeritus Professor Kazuo Achiwa (University of Shizuoka) and Dr. Kimio Furuhata (Kitasato University) for guidance on carbohydrate chemistry, and thank Professor Takashi Suzuki (University of Shizuoka) for warm and continuous support of our research.
比較してかなり阻害活性が向上した。この知見は、C-4 位を修 飾した Neu5Ac2en 誘導体が抗パラインフルエンザウイルス治 療薬の開発に非常に有用であることを示している

\section{References}

1. a) Schauer, R. (2000) Glycoconj. J. 17, 485-499; b) Varki, A. (1993) Glycobiology 3, 97-130.

2. a) von Itzstein, M., and Kiefel, M. J. (1997) In Carbohydrates in Drug Design (Witczak, Z. J., and Nieforth, K. A., eds.) pp. 39-82, Marcel Dekker, New York; b) Kiefel, M. J., and von Itzstein, M. (2002) Chem. Rev. 102, 471-490.

3. a) Collins, P. L., Chanock, R. M., and McIntosh, K. (1996) Parainfluenza viruses. In Fields Virology (Fields, B. N., Knipe, D. M., and Howley, P. M. eds.) pp. 1205-1241, Lippincott-Raven, Philadelphia; b) Murphy, B. R. (1988) Parainfluenza viruses. In Infectious Diseases (Gorbach, S. L., Bartlett, J. G., and Blacklow, N. R., eds.) pp. 2155-2131, W. B. Saunders Company, Philadelphia.

4. Kiefel, M. J., and von Itzstein, M. (1999) Prog. Med. Chem. 36, 1-28.

5. von Itzstein, M., and Thomson, R. J. (1997) Curr. Med. Chem. 4, 185-210.

6. von Itzstein, M., Wu, W.-Y., Kok, G. B., Pegg, M. S., Dyason, J. C., Jin, B., Phan, T. V., Smythe, M. L., White, H. F., Oliver, S. W., Colman, P. M., Varghese, J. N., Ryan, D. M., Woods, J. M., Bethell, R. C., Hotham, V. J., Cameron, J. M., and Penn, C. R. (1993) Nature 363, 418423.

7. a) Mack, H., and Brossmer, R. (1987) Tetrahedron Lett. 28, 191-194; b) Kok, G. B., Campbell, M., Mackey, B., and von Itzstein, M. (1996) J. Chem. Soc., Perkin Trans. 1, 2811-2815.

8. McClellan, K., and Perry, C. M. (2001) Drugs 61, 263-283.

9. Honda, T., Kubo, S., Masuda, T., Arai, M., and Kobayashi, Y. (2009) Bioorg. Med. Chem. Lett. 19, 2938-2940.

10. Crennell, S., Takimoto, T., Portner, A., and Taylor, G. (2000) Nat. Struct. Biol. 7, 1068-1074.

11. Alymova, I. V., Taylor, G., Takimoto, T., Lin, T.-H., Chand, P., Babu, Y. S., Li, C., Xiong, X., and Portner, A. (2004) Antimicrob. Agents Chemother. 48, 1495-1502.

12. Lawrence, M. C., Borg, N. A., Streltsov, V. A., Philling, P. A., Epa, V. C., Varghese, J. N., Mckimm-Breschkin, J. L., and Colman, P. M. (2004) J.Mol.Biol. 335, 1343-1357.

13. a) Varsanyi, T. M., Kövamees, J., and Norrby, E. (1991) J. General Virology 72, 89-95; b) Merson, J. R., Hull, R. A., Estes, M. K., and Kasel, J. A. (1988) Virology 167, 97-105.

14. a) Ikeda, K., Sano, K., Ito, M., Saito, M., Hidari, K., Suzuki, T., Suzuki, Y., and Tanaka, K. (2001) Carbohydr. Res. 330, 31-41; b) Suzuki, T., Ikeda, K., Koyama, N., Hosokawa, C., Kogure, T., Takahashi, T., Hidari, K., Miyamoto, D., Tanaka, K., and Suzuki, Y. (2001) Glycoconjugate J. 18, 331-337.

15. Malet, C., and Hindsgaul, O. (1996) J. Org. Chem. 61, 4649-4654.

16. Ikeda, K., Konishi, K., Sano, K., and Tanaka, K. (2000) Chem. Pharm. Bull. 48, 163-165.

17. Ikeda, K., Sato, K., Nishino, R., Aoyama, S., Suzuki, T., and Sato, M. (2008) Bioorg. Med. Chem. 16, $6783-6788$.

18. Rosen, T. Lico. I. M., and Chu, D. T. W. (1998) J. Org. Chem. 53, 1580-1582.

19. Ikeda, K., Sato, K., Kitani, S., Suzuki, T., Maki, N., Suzuki, Y., and Sato, M. (2006) Bioorg. Med. Chem. 14, $7893-7897$.

20. Tindal, D. J., Dyason, J. C., Thomson, R. J., Suzuki, T., Ueyama, H., Kuwahara, Y., Maki, N., Suzuki, Y., and von Itzstein, M. (2007) Bioorg. Med. Chem. Lett. 17, 1655-1658.

21. Sato, K., Ikeda, K., Suzuki, T., Aoyama, S., Maki, N., Suzuki, Y. and Sato, M. (2007) Tetrahedron 63, 7571-7581.

22. Sonogashira, K. (2002) Handbook of Organopalladium Chemistry for Organic Synthesis, Vol. 1 (Negishi, A. and Meijere, D., eds.) pp. 493 -529 , Wiley-Interscience.

23. Siebeneicher, H., and Doya, S. (2002) Eur. J. Org. Chem. 1213-1220.

24. Bemics, G. W., and Murcko, M. A. (1996) J. Med.Chem. 39, 2887-2893.

25. Furuhata, K. (2004) Trends Glycosci. Glycotechnol. 16, 143-169.

26. Rostovtsev, V. V., Green, L. G., Fokin, V. V., and Sharpless, K. B. (2002) Angew. Chem. Int. Ed. 41, 2596-2599.

27. a) Yoo, E. J., Bae, I., Cho, S. H., Han, H., and Chang, S. (2006) Org. Lett. 8, 1347-1350; b) Bae, I., Han, H., and Chang, S. (2005) J. Am. Chem. Soc. 127, 2038-2039.

28. a) Ugi, I., Domling, A., and Werner, B. (2000) J. Heterocycl. Chem. 37, 647-658; b) Huang, Z., Schneider, K. C., Benner, S. A. (1991) J. Org. Chem. 56, 3869-3882.

29. Nishino, R., Ikeda, K., Hayakawa, T., Takahashi, T., Suzuki, T., and Sato, M. (2011) Bioorg. Med. Chem. in press, doi:10.1016/ j.bmc.2011.02.010 


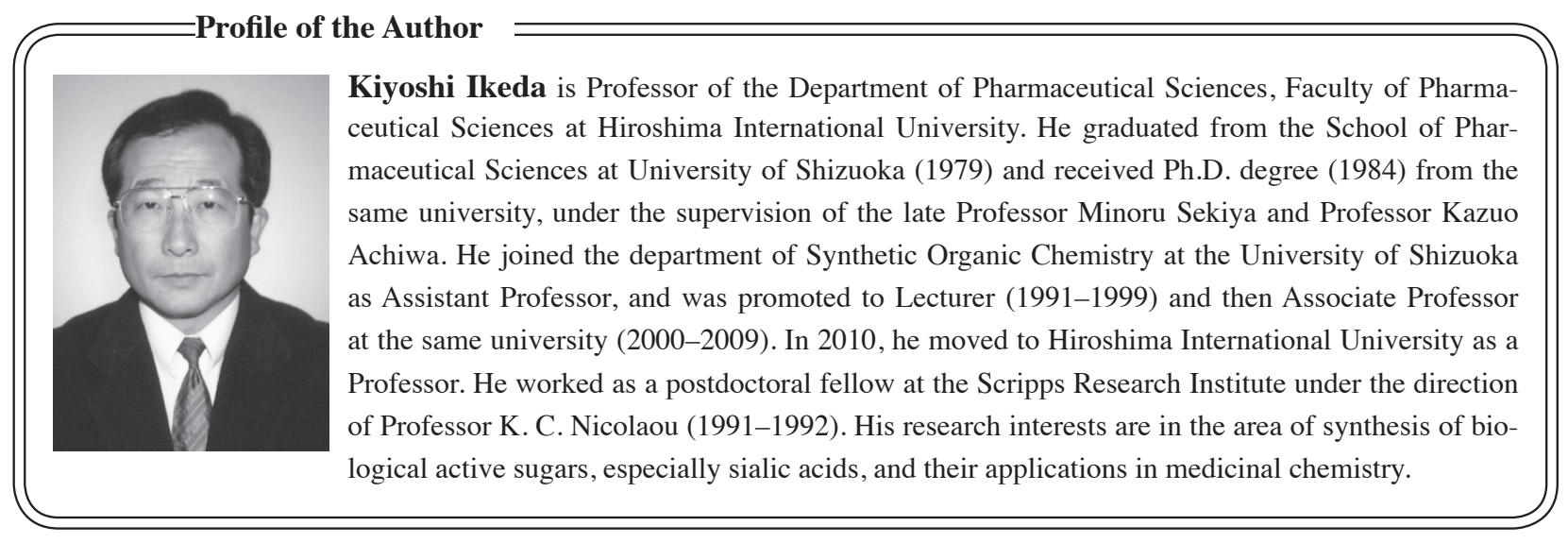

